\title{
Results of Significance Testing at 41DW269 Dewitt County, Texas
}

Sterling $\mathrm{H}$. Hays

James T. Abbott

Texas Department of Transportation

Follow this and additional works at: https://scholarworks.sfasu.edu/ita

Part of the American Material Culture Commons, Archaeological Anthropology Commons, Environmental Studies Commons, Other American Studies Commons, Other Arts and Humanities Commons, Other History of Art, Architecture, and Archaeology Commons, and the United States History Commons

Tell us how this article helped you.

This Article is brought to you for free and open access by the Center for Regional Heritage Research at SFA ScholarWorks. It has been accepted for inclusion in Index of Texas Archaeology: Open Access Gray Literature from the Lone Star State by an authorized editor of SFA ScholarWorks. For more information, please contact cdsscholarworks@sfasu.edu. 
Results of Significance Testing at 41DW269 Dewitt County, Texas

\section{Licensing Statement}

This is a work produced for the Texas Department of Transportation (TxDOT) by the report producer. TxDOT and the report producer jointly own all rights, title, and interest in and to all intellectual property developed under TXDOT's contract with the report producer. The report may be cited and brief passages from this publication may be reproduced without permission provided that credit is given to both TxDOT and the report producer. Permission to reprint an entire chapter, section, figures or tables must be obtained in advance from either the Supervisor of the Archeological Studies Branch, Environmental Affairs Division, Texas Department of Transportation, 125 East 11th Street, Austin, Texas, 78701 or from the report producer. 


\title{
Results of Significance testing at 41DW269 \\ Dewitt County, Texas
}

\author{
By \\ Sterling H. Hays \\ and \\ James T. Abbott
}

\author{
With ContributionsFrom \\ Barbara A. MEISSNER \\ Center for Archaeological RESEARCH, \\ University of TeXas at SAMANTONIO \\ AND \\ L. E. GARner \\ Bureau of Economic Geology, \\ University OF TeXas at Austin
}

1998

\section{Archeology Studies Program \\ Cultural Resource Management Section \\ Environmental Affairs Division \\ Texas Department of Transportation}

TXDOT

ENVIRONMENTAL AFFAIRS DIVISION CULTURAL RESOURCES LIBRARY. 


\section{ACKNOWLEDGEMENTS}

This project was completed with the assistance of a great many people. In addition to the authors, participants from the Environmental Affairs Division at TxDOT include A I McGraw, J esus"Chuy" Gonzales, Edith J aurrieta,Brett Harkwell, and Nancy Kenmotsu. Much of the local legwork for securing permission and equipment was performed by Dennis Nielsen, Environmental Coordinator for the Yoakum District. Dennis Nielsen also assisted in the testing investigations. Lonnie Gregorcyk, Area Engineer in the Yoakum District, was instrumental in re-designing the bridge so that site impacts could be avoided. Other Yoakum District employees who participated in the archeological investigation of 41DW269 include David Kelley, Wayne Gerbert, Daniel Perez, Ruben Garcia, Matthew Fox, Kyle Heinamenn, Rodney Straight, Jim Crawford, Tim Kalich, and Robert Pustka. Surveying of the site with a total data station was performed by Matusek Engineering, Inc. We are also indebted to Mr. E. H. "Smitty" Schmeidlin, the local Archeological Steward, and Mrs. Patsy Gable of the Cuero Museum, who were also on-site at times during the investigation and contributed their expertise. Permission to conduct the work was granted by the landowner, Mrs. Sarah Aronstein. She and her sisters graciously visited the site during our work there, and we could not have done the work without their assistance. Thanks are due to all. 


\section{AbSTRact}

Site 41DW269 was tested by Texas Department of Transportation (TxDOT) archeologists in July of 1997 . The investigations were conducted in the right-of-way of a proposed bridge replacement project on DeWitt County Road 122 at its crossing of Clear Creek. The investigations at Site 41DW269 consisted of mechanical trenching for archeological prospection and stratigraphic evaluation of the site, and the manual excavation of two $1 \mathrm{x} 1 \mathrm{~m}$ test units and two shovel tests.

Site 41DW269 is a multi-component terrace site with cultural deposits ranging in age from the Early Archaic through the Late Archaic. Two discrete alluvial fills, both containing cultural material, underlie the terrace. Unit 1 forms the core of the terrace and consists of a dark brown, sandy to silty loam to clay loam containing abundant secondary calcium carbonate. Unit 2 consists of a very dark grayish brown to black loam that represents a veneer of more recent overbank deposits that is approximately 1.0 to $1.2 \mathrm{~m}$ thick. In addition, two younger alluvial fills (Units 3 and 4) are present across the stream and at the base of the cutbank forming the northern site boundary. Testing of the site revealed two clearly distinct prehistoric cultural strata within deep alluvial deposits, and a single pit-like feature. The first cultural deposit is associated with Unit 1, and consists of a sparse assemblage of mineralized bone and lithic material extending from approximately $120-180 \mathrm{~cm}$ below the present ground surface. On the basis of a single radiocarbon age and a diagnostic Guadalupe tool, this component is believed to date to the Early Archaic. The second cultural deposit is associated with the upper veneer, and extends from approximately $10 \mathrm{~cm}$ to $110 \mathrm{~cm}$ below the surface. Although this deposit could not be subdivided based on the limited excavation data, it contains a cultural debris associated with Late Archaic and possibly Middle Archaic occupations.

Due to the deep and stratified nature of the deposits and the diversity of artifactual assemblages at the site, 41DW269 is considered eligible for inclusion in the National Register of Historic Places and for designation as a State Historic Landmark. 


\section{Table of Contents}

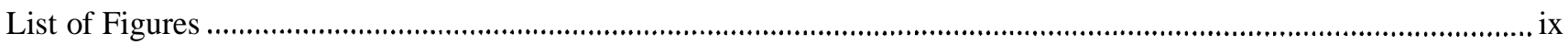

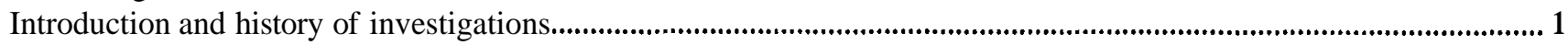

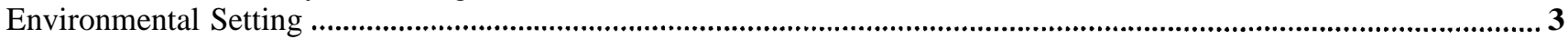

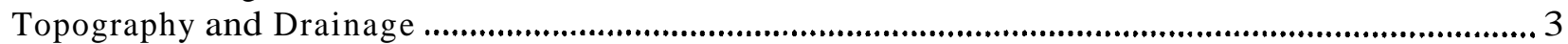

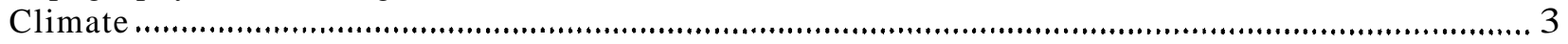

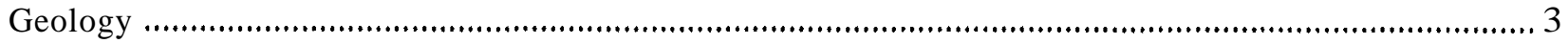

Soils .................................................................................................................................................. 3

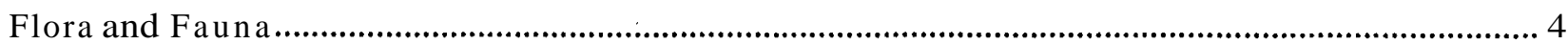

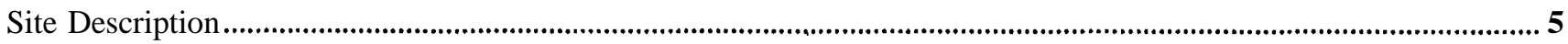

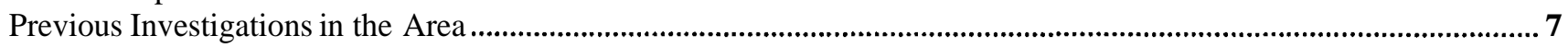

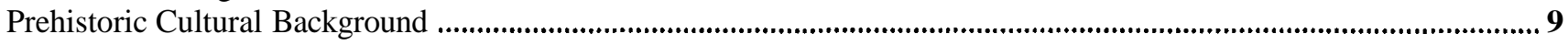

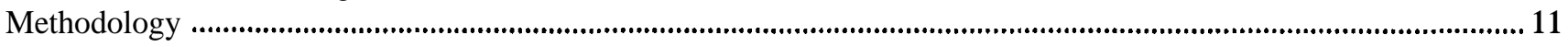

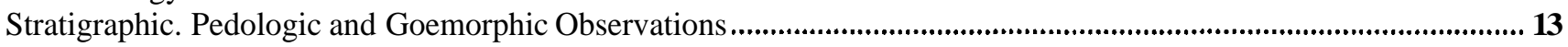

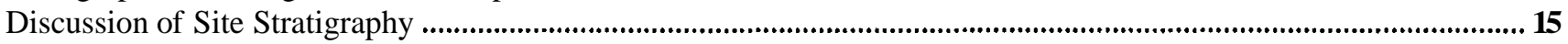

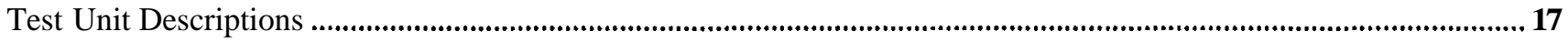

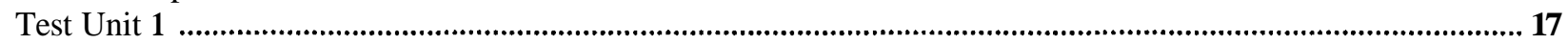

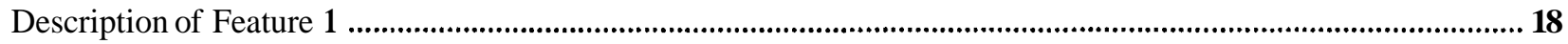

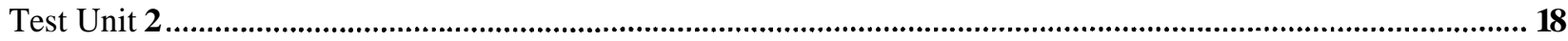

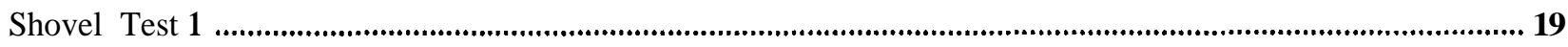

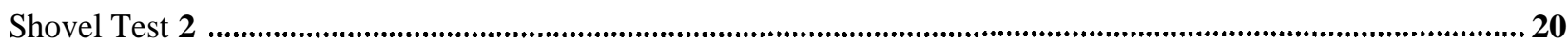

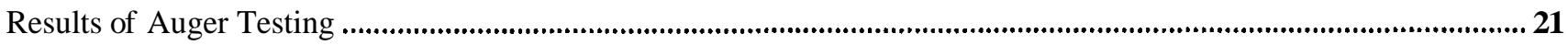

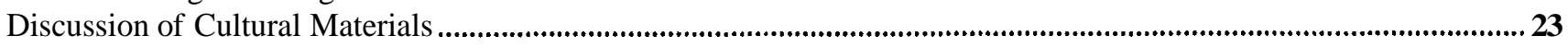

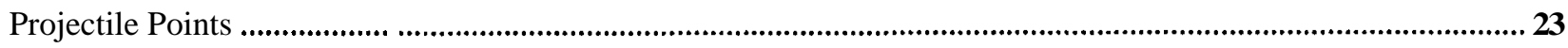

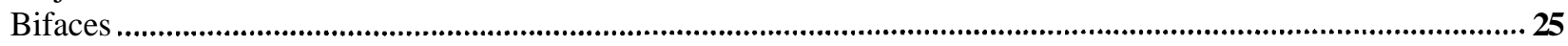

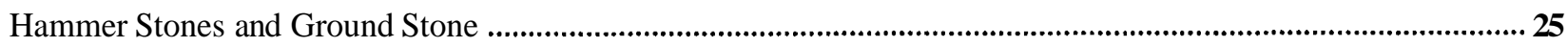

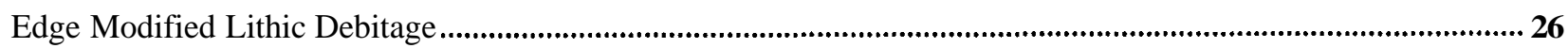

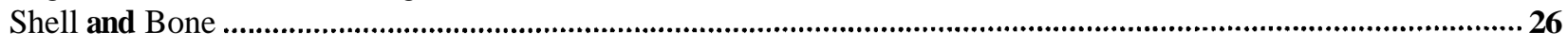

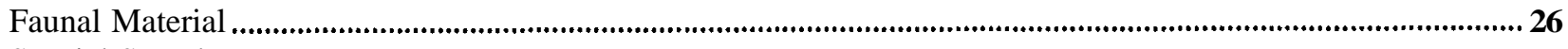

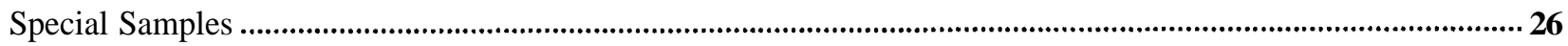

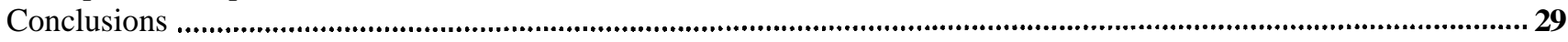

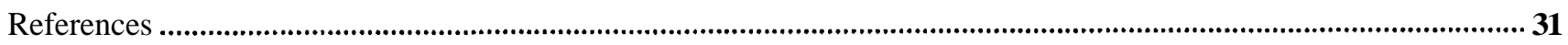

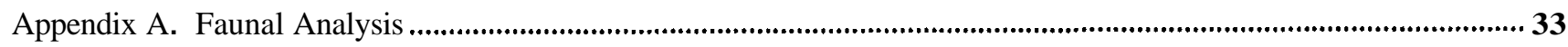

Appendix B. Thin-section Description of Carbonate Specimen ............................................................................39. 


\section{LiST OF Figures}

Figure 1. Location of Site 41DW269

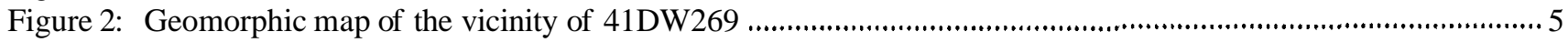

Figure 3: Contour map of 41DW269 and vicinity. showing the location of test units .................................................. 6

Figure 4: Aerial stereopair photograph of the vicinity of 41DW269 ........................................................................ 10

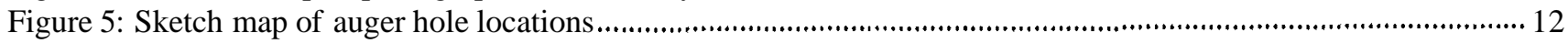

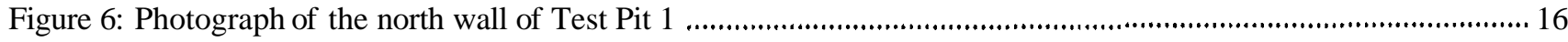

Figure 7: Schematic profiles of the nine auger holes excavated at 41DW269 .............................................................22

Figure 8. Diagnostic and other distinctive artifacts from surface and cutbank contexts ................................................... 24

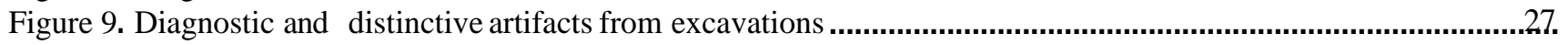

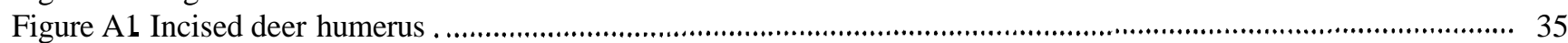

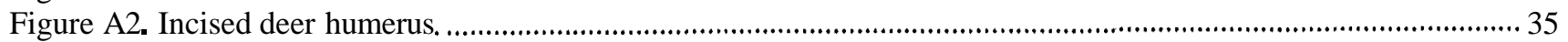

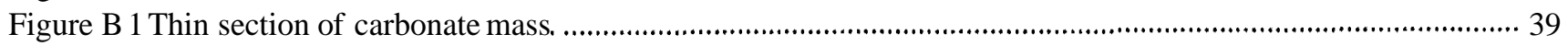

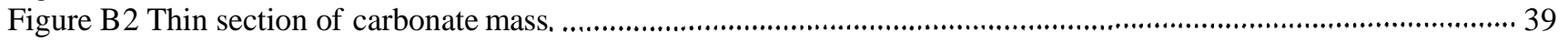




\section{INTRODUCTION AND HISTORY OF INVESTIGATIONS}

This report describes the results of test excavations conducted at site 41DW269 in northern DeWitt County, Texas. This is the location of the planned replacement of an existing steel pony truss bridge over Clear Creek on County Road 122 in north-central DeWitt County (Figure 1) with a pre-cast concrete structure. Site 41DW269 was discovered and recorded by TxDOT Archeologist Sterling Hays in October of 1996 during the preliminary survey for the project. The site was confined to a terrace above the south bank of Clear Creek, and covers an area approximately 100 by 75 meters in size. The Clear Creek cutbank exposed cultural strata ranging from the natural ground surface to a depth of approximately 2.0 meters below natural ground surface, with most of the material concentrated in the upper meter of the terrace fill. One possible Late Archaic projectile fragment was found on the surface in the cut bank of the stream. Other artifacts collected consisted of sparse burned rocks, a small, thick, ovate biface, mussel shell, and faunal remains.

In June of 1997, James Abbott, A I McGraw, and J esusGonzalez of the Environmental Affairs Division and Dennis Nielsen of the Yoakum District returned to the site to complete the recording and begin preliminary significance assessment. At that time, three and one half ten centimeter thick levels were excavated in a $1 \times 1 \mathrm{~m}^{2}$ manual test pit, Test Unit 1 . In addition, one mechanical trench was completed north of the creek and a second trench south of the creek was begun. Both the manual excavation unit and the mechanical trench were terminated when the crew was informed by District personnel that, contrary to previous information, legal right of entry to the proposed project area had not been obtained.

In July of 1997, access to the land south of the creek was obtained, and Sterling Hays, James Abbott, Jeslis Gonzalez, and Edith Jaurrieta of the Environmental Affairs Division and Dennis Nielsen of the Yoakum District returned to the site to continue the work which had been begun in June. At that time, Test Unit 1 and the second mechanical trench, Trench 2, were re-opened and continued. A third mechanical trench (Trench 2), a second manual $1 \times 1 \mathrm{~m}$ test pit (Test Unit 2), and two manual shovel tests (ST 1 and ST 2) were also excavated during this visit. Test Unit 1 was dig to a depth of 110 $\mathrm{cm}$ below the modem ground surface. Test Unit 2 was situated on a safety bench in Trench 2 , and extended from 110 to $190 \mathrm{~cm}$ below the modem ground surface. Shovel Test 1 was situated between Test Unit 1 and Trench 2, and extended to $100 \mathrm{~cm}$ and $50 \mathrm{~cm}$ below ground surface, respectively.

On the basis of the data recovered during the testing conducted in July, 41DW269 was determined to be eligible for the National Register of Historic Places and for designation as a State Archeological Landmark. This finding was concurred with by the Department of Antiquities Protection, Texas Historical Commission, in a letter dated December 2, 1997. However, because the projected costs of mitigation were considered prohibitive by DeWitt County, a field visit and discussion was conducted in early November, 1997 between representatives of the Yoakum District, the Environmental Affairs Division, and the Department of Antiquities Protection, Texas Historical Commission, to determine if the bridge could be redesigned to avoid or minimize impacts to the site. As a result of this meeting, an alternate design was proposed that would limit impacts to the area beneath and slightly to the west of the current road, avoiding the relatively rich area of the site to the east.

On Monday, December 8, 1997 a series of nine auger holes were excavated and examined within the revised footprint of the bridge footing and approach. This auger testing was conducted to determine if there were cultural deposits beneath the road that would require mitigation of that portion of the site. The results of these investigations indicated that no significant cultural deposits would be impacted by the revised design. This finding was concurred with by the Texas Historical Commission, Department of Antiquities Protection, in a letter dated January 7, 1998. The following report presents the results of the investigations outlined above. 
This Page Redacted Per THC Policy 


\section{Environmental Setting}

\section{Topography and Drainage}

Site 41DW269 is situated along Clear Creek which is a sandy bed meandering stream that originates in western DeWitt County and flows east to a confluence with Sandies Creek north of Cuero. The site is situated on a $T_{2}$ Holocene terrace overlooking the south side of the stream. The terrace lies approximately $5.0 \mathrm{~m}$ above the modem thalweg, and forms the principal alluvial surface in the valley (Figure 2). There is a narrow, modem low-water floodplain ( $\left.T_{0}\right)$ surface at the base of the $T_{2}$ scarp that lies approximately $50 \mathrm{~cm}$ to $1 \mathrm{~m}$ above the modem channel, and a sloping $\mathrm{T}_{1}$ surface point bar on the opposite side of the stream that rises gradually from approximately $1.5 \mathrm{~m}$ to approximately $3 \mathrm{~m}$ above the modem thalweg. No higher terraces are apparent in this reach of Clear Creek. The surrounding topography is rolling, and is primarily in improved pasture and cultivation. Abrupt scarps and breaks in slope are rare except on the margin of the modem stream channels. Wooded areas are restricted to the lowlands along streams and localized remnants in the uplands. The elevation of the site is approximately $85 \mathrm{~m}(278 \mathrm{ft})$. Local relief varies from approximately $81 \mathrm{~m}(265 \mathrm{ft})$ in the channel to $120 \mathrm{~m}$ (393 ft) on the surrounding hilltops.

\section{Climate}

The climate of DeWitt County is humid subtropical. The region is characterized by predominantly megathermal, neotropical temperatures. Summers are hot, and winters are relatively mild, although they may be interrupted by occasional mild freezes associated with frontal passages (Norwine 1995). Average daily high temperatures at Cuero vary from 64.3' $\mathrm{F}(17.9 \mathrm{C})$ in January to 97.7' F (36.4 C) in August. The record high for Cuero is $110 \mathrm{~F}(43.3 \mathrm{C})$ which occurred in July, 1954 , and the record low is $2 \mathrm{~F}(-16.6 \mathrm{C})$, which occurred in January 1949. Precipitation averages 33.17 inches $(843 \mathrm{~mm})$ per year, but is relatively variable on a year-to-year basis (Miller 1978). Norwine (1995) notes that one of the hallmarks of south Texas climate is extreme precipitation variability, but this tendency is more pronounced to the south and west. There is typically a pronounced water deficit on a yearly basis. There are two precipitation peaks during the year, with relatively high rainfall occurring during late spring and again during late summer and early autumn. The most intense precipitation occurs in conjunction with infrequent tropical storms and hurricanes; the record for a single day is 10.9 inches $(277 \mathrm{~mm})$ which occurred in conjunction with Hurricane Beulah in September 1967. Much of the precipitation in the area occurs in relatively brief, intense thunderstorms that can generate significant runoff, but more protracted, gentle rains associated with warm fronts are also common.

\section{Geology}

The study area is situated in the West Gulf Coastal Plain section of the Coastal Plains physiographic province (Fenneman 1938). This area is characterized by a succession of offlapped sedimentary rock bodies of Cretaceous to Recent age that outcrop in narrow to relatively wide, shore-parallel bands. The formation underlying the study area is the Miocene Oakville Sandstone, which crops out in a northeast-southwest trending band approximately $5-15 \mathrm{k} \mathrm{m}$ wide. The Oakville Sandstone consists of medium-grained, light yellowish gray to light gray calcareous sandstone that contains fragments of petrified wood, siliceous pebbles, vertebrate fossils, and reworked Cretaceous fossils and is interbedded with yellowish gray calcareous clay (Bames 1974). It is generally more resistent to erosion than formations immediately up-section (e.g., the Miocene Fleming Fm. and Pliocene Goliad Fm.) and down-section (e.g., the tuffaceous Miocene Catahoula Fm. and upper Eocene Whitsett, Manning, Wellborn, Caddell, and Yegua Formations), and forms a prominent cuesta termed the Bordas-Oakville Escarpment. Dissection of this cuesta has resulted in the rolling topography that surrounds the site, which exhibits relatively strong relief in comparison to surrounding areas on the inner Coastal Plain.

\section{SoILS}

The site is situated in the Sarnosa-Shiner General Soil Association (Miller 1978). The Samosa-Shiner Association consists of nearly level to sloping, welldrained, moderately permeable, calcareous loamy soils developed primarily on uplands. Comparision of the general soils map of DeWitt County (Miller 1978) with extant geologic mapping (Bames 1974) suggests that the Samosa-Shiner Association, together with the SamosaMonteola Association, is typical of the outcrop of the Oakville Sandstone. Soils mapped in the immediate vicinity of the site include Samosa fine sandy loam on the higher terraces and surrounding slopes, Meguin silty clay loam on the lower terraces and floodplain, and the 
Weesache sandy clay loam and Denhawken-Elmendorf complex on the higher upland surfaces. The Sarnosa series are Typic Calciustolls, and exhibit an A-B-Bk-Ck profile developed in sandy bedrock. They are not typical of Holocene stream terraces, suggesting that the classification of soils on the site proper is not accurate. Meguin soils are Fluventic Haplustolls, and typically exhibit an A-B-C profile developed in silty clay loam alluvium. Weesache, Denhawken, and Elmendorfer soils are Mollisols and Inceptisols developed in sandy to clayey bedrock.

\section{Flora and Fauna}

The site lies near the boundary between the Texan and Tamaulipan biotic provinces of Blair (1950). The biota in this region represents a mixture of taxa typical of the forests and grasslands to the north and east, and the scrublands to the south and west. The typical climax plant species in the upland environment include little bluestem, Arizona cottontop, pinhole bluestem, lovegrass tridens, plains lovegrass, plains bristlegrass, hooded windmillgrass, pink pappusgrass, indiangrass, silver bluestem, buffalograss, curly mesquite, live oak, kidneywood, range ratany, guajillo, and cenizo. The floodplain and terraces are heavily wooded with a mixed riparian assemblage that includes oak, pecan, hackberry, elm, ash, woody vines, sedges, grasses like indiangrass, Virginia wildrye, rustyseed paspalum, redtop panicum, and long-tom, and forbs like snoutbean, wildbean, and partridgepea (Miller 1978). A variety of fauna are also typical of the area. At least 49 species of mammals (none of which are endemic) occur in the Texan Province, while at least 61 species of mammals are present in the Tamaulipan Province (Blair 1950). While all of these species do not occur in the transitional zone between the two provinces, lack of diversity in available biotic resources was probably not a problem for prehistoric inhabitants of the region. Major economic species known to have been present in the region at one point or another include white-tailed deer, pronghorn, bison, turkey, and cottontail rabbit. 


\section{Site Description}

The County Road (CR) 122 project area is located approximately $12 \mathbf{~ k ~ m}$ north of the community of Yorktown in DeWitt County, Texas on Clear Creek. Site 41DW269 is situated along the southern terrace of the creek and extends approximately 33 meters west of CR 122 and 66 meters east of the road for a total width of 100 meters (figure 3 ). The site's northern boundary is clearly delineated by the eroded bluff along the southern bank of the creek. The southern limits of the site are delineated by a shallow drainage 35 meters south of the bluff face which flows northeastward into Clear Creek. The surface of the site is relatively flat. The relative central portions of the site are approximately $50 \mathrm{~cm}$ higher in elevation than the perimeter. The site rests in a terrace that lies approximately 4.5 to 5.0 meters above Clear Creek.

Numerous cultural materials can be seen eroding from the bluff face at depths ranging from the natural ground surface to 1.5 meters below the ground surface, where an apron of erosional spoil obscures visibility. The types of cultural materials that are visible on the surface of the site and in the erosional bluff face include projectile points, bifacial implements, ground stone, all stages of lithic reduction debitage, ochre, fresh and salt water bivalve shells and bones of small to large mammals. The stratigraphy of the site is described in detail in a following section.

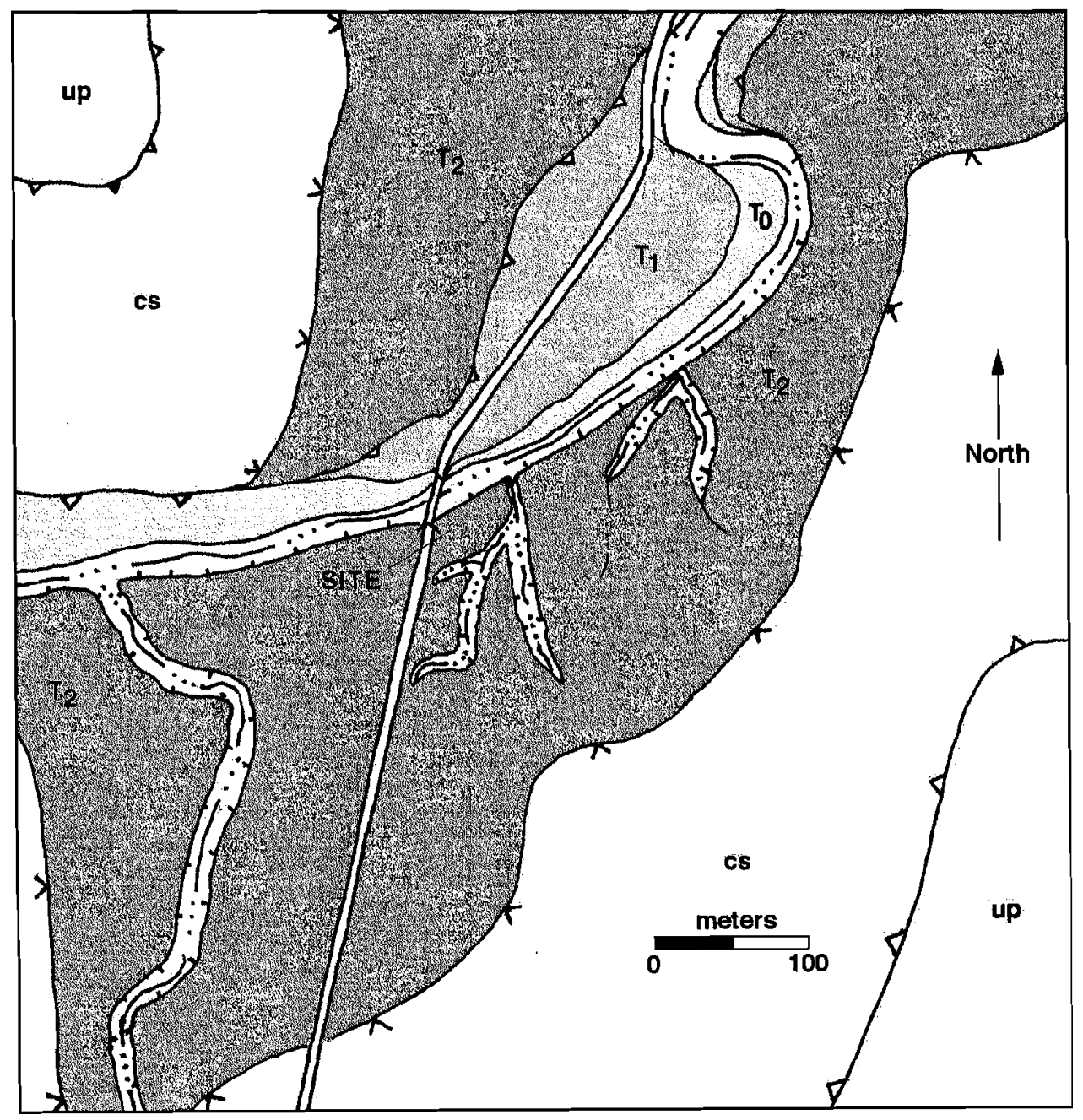

Figure 2: Geomorphic map of the vicinity of 41DW269, prepared from aerial stereopair photographs. The designations $T_{0}, T_{1}$ and $T_{2}$ refer to alluvial surfaces, cs refers to colluvial slope and up refers to the relatively level upland. 


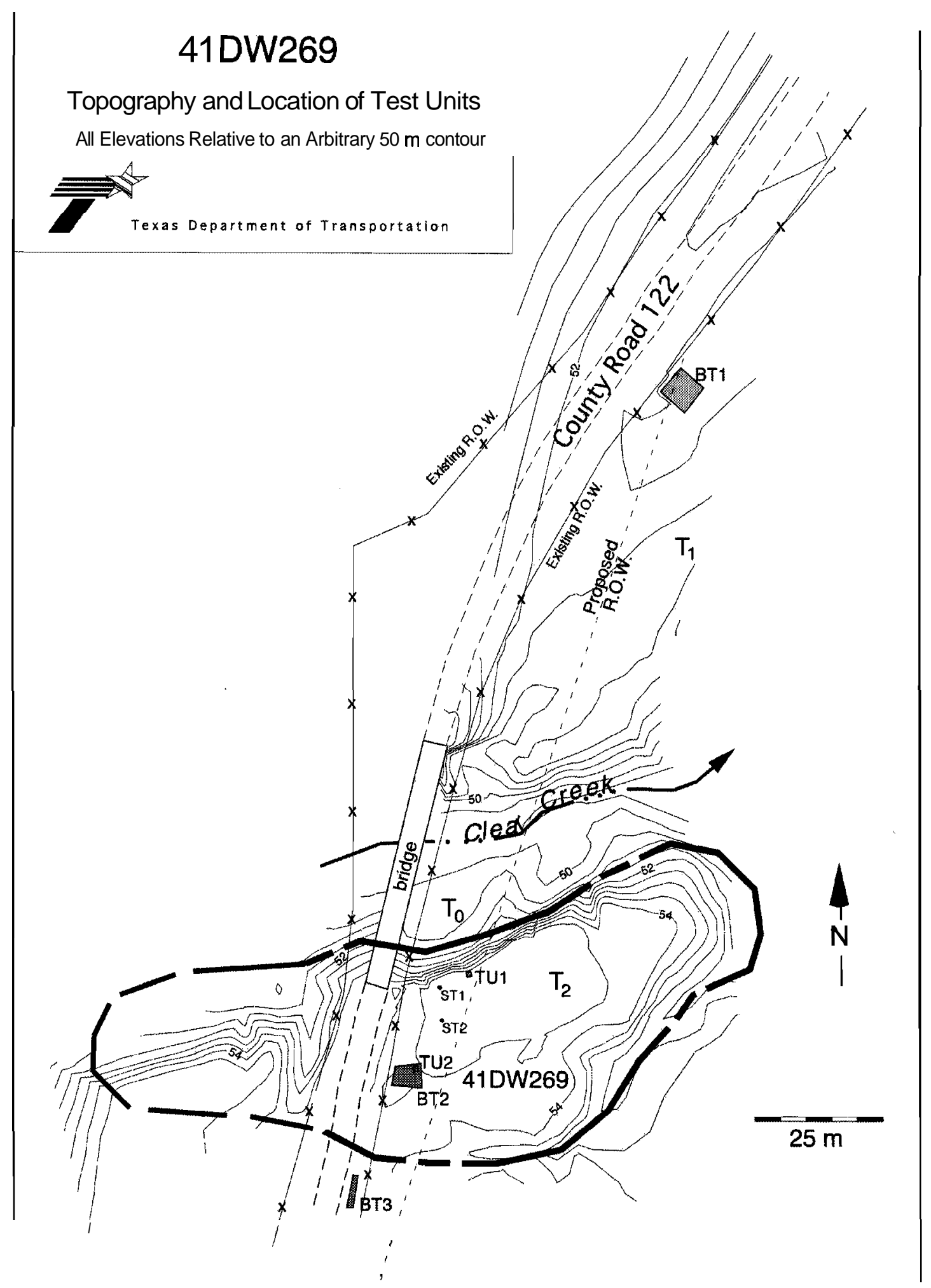

Figure 3: Contour map of 41DW269 and vicinity, showing the location of test units. 


\section{Previous Investigations in the Area}

Although little previous professional archeology has been conducted in DeWitt County, sites in surrounding counties have been the focus of sporadic interest since 1932. Much of this work took place in near the community of Victoria, about 40 miles southeast of 41DW269. Several important early investigations were conducted at 41VT1, the Morhiss Site, by A. T. Jackson, A. M. Woolsey, and W. A. Duffen between 1932 and 1940. In subsequent decades, avocationalists have played a large role in the identification and investigation of the area's archeological sites. Despite these efforts, the regional cultural history remains poorly understood in comparison with the more thoroughly investigated central Texas region. Archeological investigations that offer limited comparative data include 41LK28, the Loma Sandia Site, the Choke Canyon Reservoir project, and the Cuero Reservoir Project. Other sources that provide overviews of area prehistory include Hester (1980; 1995) and Tomka et al. (1997). 
$8 \quad$ Significance Testing at Prehistoric Archeological Site... 


\section{Prehistoric Cultural Background}

DeWitt County lies along the margins of the Central Coastal Plain and the Blackland Prairie Archeological Regions as defined by Prewitt (1981). The prehistoric chronology in South and Central Texas begins in the Late Pleistocene (ca. 11,000 B.P.) and continued until the first European contact in the 16th century A.D. The following brief synthesis is based on a number of synthetic sources, primarily Hester (1980; 1995), but also including Collins (1995), and Prewitt $(1981 ; 1985)$. As Hester (1995) notes, there is insufficient data from southern Texas to provide a detailed chronology similar to those by various authors for central Texas (Prewitt 1985; Johnson and Goode 1994; Collins 1995), and it remains necessary to rely on broad chronological subdivisions (i.e., Paleoindian, Archaic, Late Prehistoric, Protohistoric).

The term Paleoindian is applied to the late Pleistocene-early Holocene aboriginal cultures whose subsistence strategies included the exploitation of extinct Pleistocene megafauna. Although a large number of surface finds demonstrate that humans were present in the Central Coastal Plains and South Texas by the end of the Pleistocene, few sites have been investigated. Isolated finds of Paleoindian diagnostics include Clovis, Folsom, Plainview, Golondrina, and Angostura. Investigated Paleoindian sites are rare in the region, although a few have been investigated (e.g., 41GD 30, 41VT6, and 41VT15). Collins (1995) indicates that resources exploited by Paleoindian populations were more diverse than the stereotypical megafauna that became extinct at the end of the Pleistocene. He also suggests that Paleoindian subsistence likely included plant gathering, small mammals, turtles and reptiles as well as hunting larger mammals. Excavation results from the Berger Bluff site (41GD30) appear to support this view, as the material includes only small fauna (Hester 1995).

As used here, the term "Archaic" refers to the longlived cultural stage characterized by hunting and foraging. However, tools and faunal remains from the Paleoindian occupation levels at the Wilson-Leonard site in Williamson County and Horn Shelter No. 2 in Bosque County suggest that the shift to a subsistence economy geared primarily to foraging began prior to the Archaic. A generalized subsistence economy that emphasized foraging and collecting is suggested for the Early Archaic. However, the distinction between the late Paleoindian and early Archaic occupations is problematic and blurred, and some projectile point styles (e.g., Angostura) are attributed to Paleoindian and Early Archaic traditions by different authors.

Hester (1995) subdivides the early Archaic period into an earlier "Early Comer Notched Horizon" and a later "Early Basal Notched Horizon." The "Early Comer Notched Horizon" is associated with comer notched dart points (e.g., Martindale, Uvalde) and Guadalupe tools. The subsequent "Early Basal Notched Horizon" is characterized by the appearance of distinctive styles with deep basal notches, such as Bell and Andice points, as well as Clear Fork tools. Other tools, such as the socalled "early triangular" biface, appear to have persisted from the "Early Comer Notched" through the "Early Basal Notched" horizon. While investigated sites are few, and subsistence and settlement remain poorly understood, it appears that Early Archaic subsistence focused on a wide variety of terrestrial and aquatic resources.

The Middle Archaic in South Texas is characterized by the appearance of characteristic unnotched triangular projectile points (e.g., Tortugas, Abasolo) and a variety of unifacial and bifacial, distally-beveled tools (e.g., Nueces tools, Dimmit tools). In the central Coastal Plain, these distinctive tools co-occur with a variety of stemmed Central Texas points (e.g., Pedernales, Bulverde, Lange, Travis) and the distinctive Morhiss point, which is primarily found in sites along the central Texas coast and through the lower Guadalupe and adjacent drainage systems. In central Texas, this period appears to represent the rise to prominence of burned rock midden sites, implying a shift in the subsistence economy. On the basis of data from Choke Canyon, Hall et al. (1986) infer that a similar increase in reliance on plant foods occurred in South Texas. The Middle Archaic also marks the appearance of large cemeteries such as Loma Sandia (Taylor and Highley 1995).

The Late Archaic period appears to represent a continuation of Middle Archaic subsistence strategies. The continued presence of large burned rock features in Central and South Texas, and the increasing frequency of grinding implements, suggests that the exploitation of wild plant foods remained important. Faunal exploitation appears to have remained broad-based, although it is possible that the numbers of available bison increased. Cemeteries continued to be used, although the frequency of isolated burials appears to have increased. Characteristic diagnostics include both stemmed (e.g., Marcos, Frio, Ensor) and unstemmed triangular (e.g., Tortugas, Abasolo, and later C atanand Matamoros) points, corner-tang knives, and large bifaces. The Archaic is followed by a period that has been variously called the Neoamerican, Neoarchaic or Late Prehistoric. The Late Prehistoric is marked by the introduction of ceramics and the bow and arrow, and of concomitant 
shifts in subsistence and settlement, including increasing reliance on bison during the latter part of the period. As in Central Texas, the coastal zone appears to be characterized by a shift from small dart points to expanding stem arrow points (e.g., Scallorn) in the earlier part of the Late Prehistoric, followed by a shift to contracting stem arrow points (e.g., Perdiz) in the latter part. At the same time, small triangular dart points (e.g.,
Catan, Matamoros) persist in certain localities throughout the period. Ceramics in the inner part of the coastal plain reflect types characteristic of areas inland (e.g., Leon Plain ware) and coastal areas (e.g., Rockport ware). Some researchers identify a final phase before the Historic period termed the Protohistoric, which marks a cultural transition stimulated by the arrival of the Spanish.

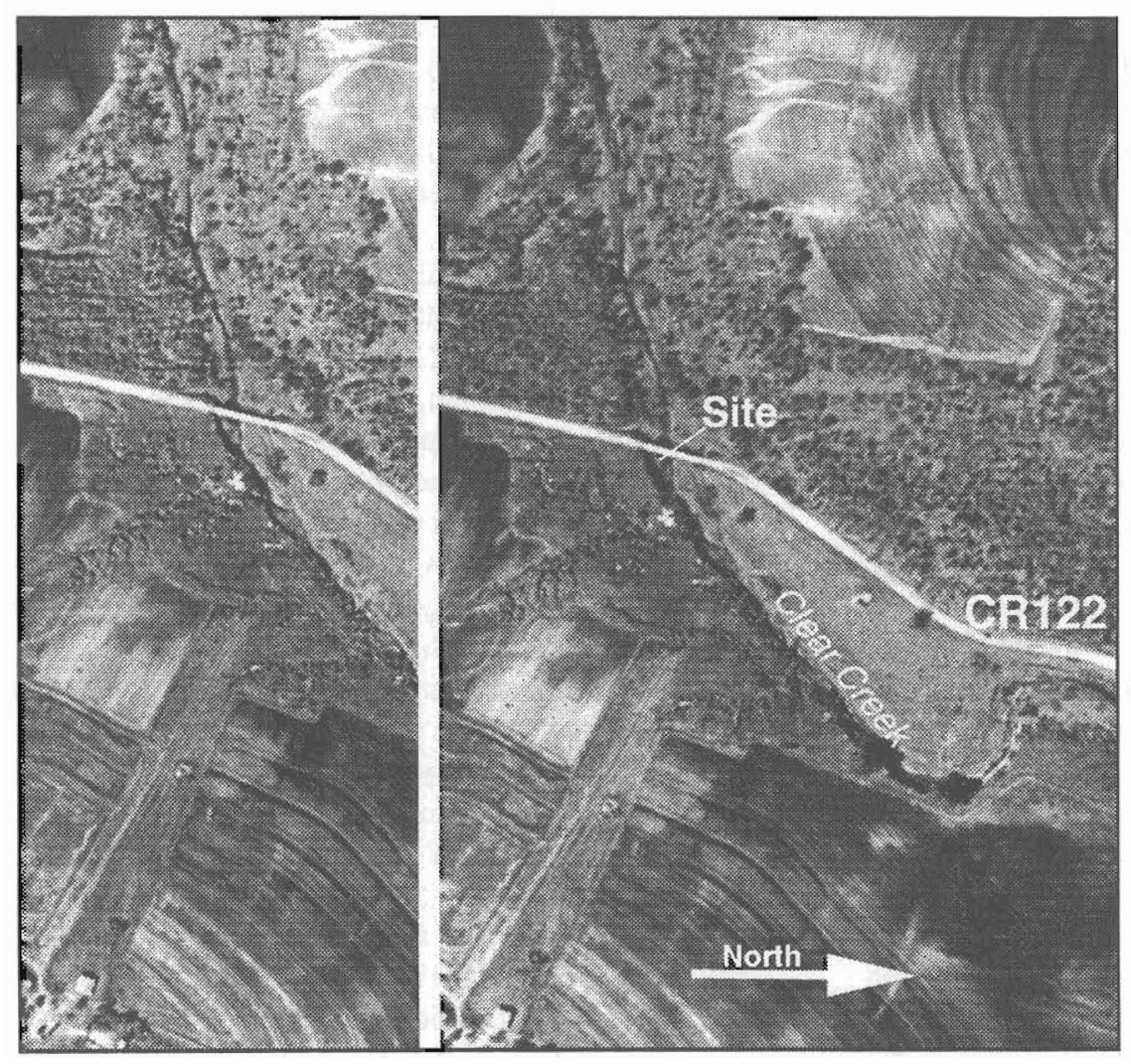

Figure 4: Aerial stereopair photograph of the vicinity of 41DW269 


\section{MethodologY}

The purpose of the current investigations was to determine if the cultural deposits at 41DW269 are stratified and intact, and to determine the nature, extent, and character of the deposits and archeological remains. The excavations were conducted to permit assessment of eligibility for inclusion to the National Register of Historic Places and designation as a State Archeological Landmark.

Backhoe trenching in the project area was conducted to examine the stratigraphy of the terrace, to prospect for deeply buried cultural material, and to determine the extent of the site observed cropping out along the cut bank. However, opportunities for trenching were limited by dense tree growth and lack of access to the site across the fence bordering the existing right-of-way, and only three trenches were excavated within the project area. Trenching was performed with a backhoe with a smoothbladed, 48 inch $(120 \mathrm{~cm})$ bucket. Backhoe Trench 1 and Backhoe Trench 2 were excavated by backing the backhoe up to the edge of the existing right-of-way and trenching over the fence, while Backhoe Trench 3 was excavated on the margin of the existing right-of-way (see Figure 3).

Mechanical excavation and release of the backdirt from the bucket was monitored by a TxDOT archeologist. Only the upper meter of BT 1 and BT 3 were recorded in detail. In the case of BT 1, detailed recording of the lower strata was precluded because of safety concerns related to the unconsolidated sands at depth, while the lower portion of BT 3 was not recorded because it was geologically similar to BT 2 , lacked cultural material, and would have required considerable time to expand to make it safe for entry. Each trench was examined and described using standard soil terminology (Olsen 1976). Although the trenches were not profiled in an archeological sense, schematic stratigraphic profiles were drawn. In addition, a section of the natural cutbank was cleaned and described using the same terminology.

Geomorphic surfaces in the vicinity of 41DW269 were mapped (see Figure 2) using field observations and aerial stereopair photographs (Figure 4). The photographs used for mapping were obtained from the Texas Natural Resource Information System (TNRIS) at the Texas Water Development Board. They dated from 1959 and had a nominal scale of 1:19,500.

Two $1 \times 1 \mathrm{~m}$ test pits were excavated on the site. Test Pit 1 was situated immediately back from the cutbank at the eastern edge of the R-0-W, while Test Pit 2 was situated on the northern safety bench of Backhoe Trench 2. In addition, two shovel tests were excavated on the terrace between Test Pit 1 and Backhoe Trench 2 (see Figure 2). All of the manually excavated soil matrix was screened through 1/4 inch hardware cloth and the artifacts collected via standard archaeological procedures. Soil samples were extracted from the matrix of Feature 1 in Test Pit 1 and snail samples were collected from both test pits. The sample from Test Unit 2 was submitted to Beta Analytic, Inc for radiocarbon analysis. The backhoe trenches, excavations units and the site were mapped with a Total Data Station, and the site was photographed. All artifacts, profiles, photographs and other materials from the testing of site 41DW269 were taken to the Environmental Affairs Division in Austin for washing, cataloging, analysis and labeling. After cleaning and labeling, the faunal remains were submitted to Barbara Meissner at the Center for Archaeological Research, University of Texas at San Antonio for analysis. In addition, a sample of an anomalous calcareous deposit found in Test Pit 1 was submitted to Ed Garner at the Bureau of Economic Geology, University of Texas at Austin, for thin section analysis. The methods and results of these outside analyses are presented in Appendix 1 and Appendix 2, respectively.

Following redesign of the bridge, nine auger holes were excavated in the area of planned impact (Figure 5) using a bobcat-mounted power auger approximately 1.2 $\mathrm{m}$ long and $35 \mathrm{~cm}$ in diameter. Each hole was typically excavated in two or three "bites", and the sediment and the hole were examined after each bite. The sides of the hole were troweled off as deeply as possible (approximately $75 \mathrm{~cm}$ ) to determine stratigraphic contacts. Although none of the auger spoil was screened, the sediment on the ground and adhering to the auger bit was carefully troweled through to determine if artifacts were present.

The land owners have stated that they wish to retain ownership of all of the artifacts on or recovered from the site. However, as of the Department's last communication, they have agreed that the cultural materials recovered from the site be curated at the Texas Archeological Research Laboratory at the J. Jake Pickle Research Center, the University of Texas at Austin. 


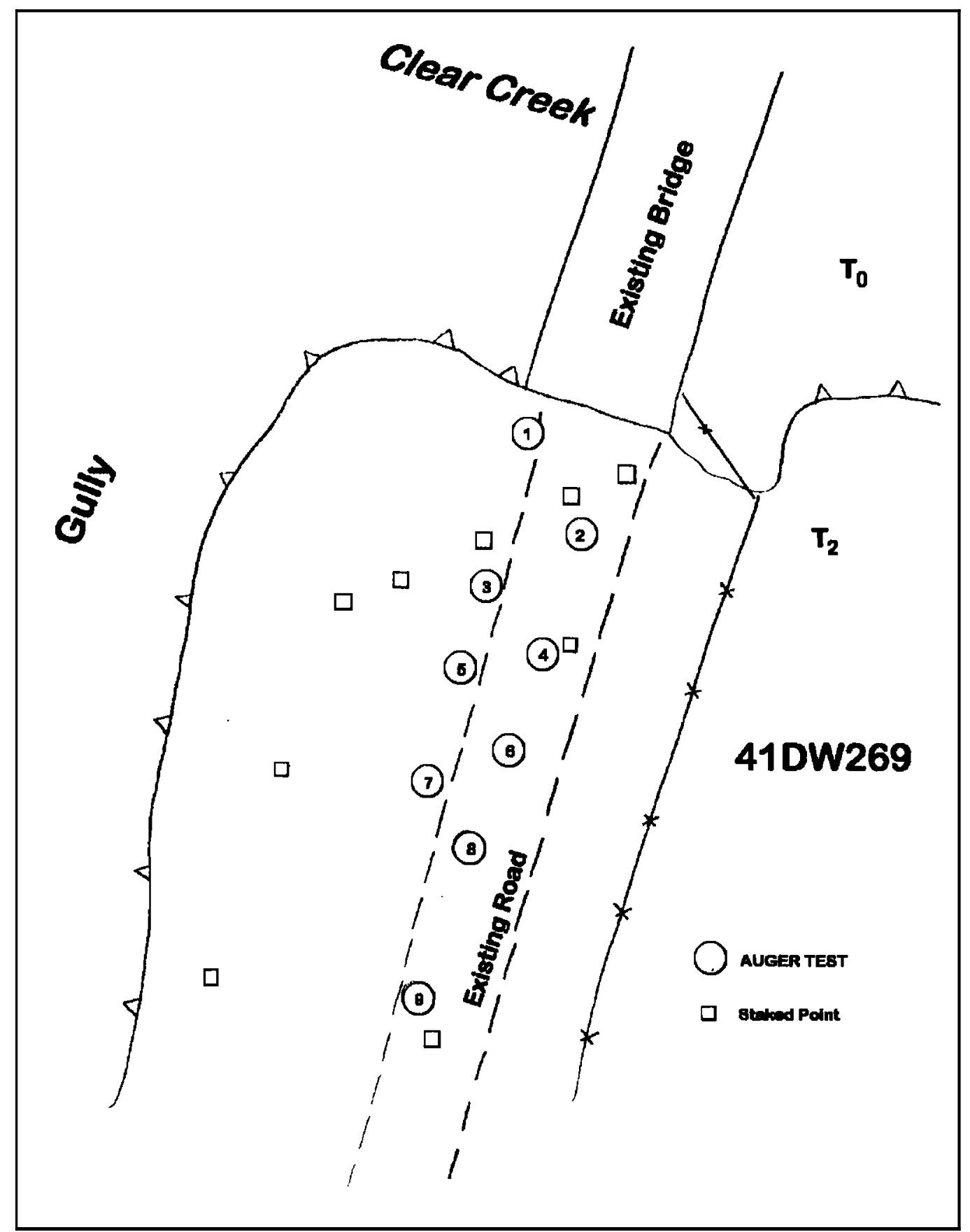

FIGURE 5: Sketch map of auger hole locations. Scale is approximately $1 \mathrm{in}=8 \mathrm{ft}$. 


\section{Stratigraphic, Pedologic and Geomorphic ObServations}

Backhoe Trench 1 was excavated to a depth of 265 $\mathrm{cm}$ on the $T_{1}$ terrace across the stream from 41DW269. It revealed a relatively weak, A-AC-C soil profile developed in stratified sandy stream alluvium. The A horizon is $20 \mathrm{~cm}$ thick and consists of massive, very dark brown (10YR2/2) sandy loam. Fine roots and bulbs (wild onion) are common throughout the horizon, which is moderately calcareous. The transitional AC horizon is $25 \mathrm{~cm}$ thick and consists of massive, dark brown (10YR 3/3) loamy fine to medium sand. Faint krotovina (burrow fills) are apparent throughout the horizon, which varies from moderately to strongly calcareous. It grades down into the $\mathrm{C} 1$ horizon, which consists of grayish brown (10YR5/2), weakly stratified loamy point bar sands. This horizon is $130 \mathrm{~cm}$ thick and exhibits faint subhorizontal stratification, common faint krotovina, and an increasing number of small siliceous pebbles with depth. It is moderately to strongly calcareous. This thick horizon grades abruptly into $10 \mathrm{~cm}$ of massive, dark brown sandy calcareous loam ( $\mathrm{C} 2$ horizon) and then into massive, iron-stained pale brown coarse sands that probably represent a channel deposit. The basal sands are quite clean and relatively well-sorted, and are weakly to moderately calcareous. No cultural material was noted in the trench.

Backhoe Trench 2 was excavated to a depth of $2.0 \mathrm{~m}$ on the $T_{2}$ terrace on the south side of the stream. It exhibits an A-Bt-Bk profile developed in loamy alluvium. The A horizon is $50 \mathrm{~cm}$ thick, and consists of a black (10Y R2/1), weak granular loam. It is moderately calcareous and contains common woody roots. It grades down into very dark gray (10Y R 3/1), weak medium blocky clay loam horizon that was interpreted in the field as a probable Bt horizon on textural grounds, although obvious macroscopic evidence of significant clay translocation is lacking. This horizon is $45 \mathrm{~cm}$ thick. Although the horizon is strongly calcareous throughout, visible secondary carbonate is limited to a few small, hard nodules that occurred within a few $\mathrm{cm}$ of the clear, smooth basal contact. The underlying $2 \mathrm{~B} 2 \mathrm{k}$ horizon is $40 \mathrm{~cm}$ thick, and consists of massive, dark brown (10YR 3/3) loam. It contains a large number of very large, irregularly shaped carbonate concretions, which include subrounded nodular concentrations up to about $2 \mathrm{~cm}$ in diameter and elongate and branching rhizoliths up to 8 $\mathrm{cm}$ in length and $1-2 \mathrm{~cm}$ in diameter. Although not quantified in the field, the concentration of these masses is approximately $20-25 \%$ by volume. Despite this high concentration within the matrix, the masses are practically invisible in profile from any distance because they are exactly the same color as the surrounding matrix. When broken, most masses exhibit concentric growth structures and complex, brecciated interiors with open voids and smooth, microcrystalline calcite. Both the masses and the surrounding matrix are violently calcareous. The concentration of these masses is equally high in the 2B3k horizon, which extends to the base of the trench at approximately $2 \mathrm{~m}$ bgs. This horizon consists of massive, dark brown (10YR 3/3) silty loam. It is also violently calcareous. Sparse cultural material, including lithic debitage and charcoal flecks, was noted in section from approximately $150 \mathrm{~cm}$ to $190 \mathrm{~cm}$.

BT 3 was excavated to a depth of approximately 260 $\mathrm{cm}$ on the $\mathrm{T}_{2}$ surface south of the stream. The surface of the trench, which was excavated within the existing R.O.W. is mantled with a thin veneer of gravel that represents road spoil. The A horizon is $40 \mathrm{~cm}$ thick, and consists of black (10YR2/1), weak granular structured clay loam that contains abundant woody roots. It is moderately calcareous. The A horizon grades rapidly into a massive, dark grayish brown (10Y R 4/2) B1 (possibly $\mathrm{B} 1 \mathrm{t}$ ) horizon $50 \mathrm{~cm}$ thick. The Blt horizon is composed of very firm, sticky clay suffused with common faint black mottles. It is strongly calcareous. As in BT 2, the designation of this horizon as an argillic horizon is based on gross textural criteria and may not be supported. No clear evidence of clay translocation was noted. The underlying $2 \mathrm{~B} 2 \mathrm{k}$ horizon is approximately $1 \mathrm{~m}$ thick, and consists of massive to very weakly coarse blocky sandy loam. Although the peds do not readily separate, they are nonetheless visible because the ped exteriors are lower chroma (10Y R3/4) than the interiors (10YR 4/4), which probably represents slight reduction imparted by water flowing through the soil cracks. The most notable aspect of the $2 \mathrm{~B} 2 \mathrm{k}$ horizon is the extremely high concentration of hard carbonate masses, which are similar to the nodules and rhizoliths observed in BT2. Both the masses and intervening matrix are violently calcareous. While still present, these hard masses are considerably smaller and less frequent in the underlying $2 \mathrm{~B} 3 \mathrm{k}$ horizon, which consists of grayish brown (10YR5/2), weak medium subangular blocky sandy clay loam. In addition to these hard carbonate masses, thick, yellowish films and filaments of carbonate are present on the ped faces. The visible carbonate is violently calcareous, while the intervening matrix is strongly calcareous.

One additional section was recorded on the cutbank of the $T_{2}$ terrace near TU 1 . It recorded a sequence that is very similar to that exposed in BT 2, but which includes much more cultural material in the upper horizons. The recorded section extends from 25 to 185 $\mathrm{cm}$ below the modem ground surface. The upper $25 \mathrm{~cm}$ 
of the section was not recorded due to erosional beveling of the terrace scarp, but all depth measurements were made relative to the level terrace surface. The A horizon extends to a depth of $45 \mathrm{cmbs}$. It consists of black (10Y R 2/1), massive to weak granular loam to clay loam. Woody roots are common to abundant, and the matrix is moderately calcareous. There is common cultural material dispersed through the horizon, including flakes, bone fragments, and snail shell. The next horizon is designated as a Bw horizon, and extends from 45 to 80 cmbs. It is composed of massive, very dark grayishbrown (10YR 3/2) fine sandy loam containing fine black mottles. Woody roots are common, and the horizon is moderately to strongly calcareous. It contains abundant artifact, including bone, occasional mussel shell fragments, and lithic debitage, and is heavily populated with land snail shells (principally rabdotus). The basal contact is clear and undulating. A heavy concentration of rabdotus shells (several hundred in physical contact) is present in one of the downward deflections in the contact; this concentration appears to represent an infilled burrow, but the margins of the feature are not distinct. Because the undulating contact appears erosional, the underlying zone is designated as a $2 \mathrm{Blk}$ horizon. It is similar in appearance to the $2 \mathrm{Bk}$ horizon exposed in BT 2 and BT 3, but with less pronounced carbonate development. It consists of massive, dark yellowish brown (10Y R 4/4) fine sandy to silty loam containing a few very coarse, diffuse-edged mottles and common distinct mottles representing krotovina infilled with darker surface sediment. There are a few relatively large, hard carbonate nodules dispersed throughout the matrix, which is strongly calcareous. No cultural material was noted below about $5 \mathrm{~cm}$ beneath the pronounced upper contact. The lower contact, which lies $165 \mathrm{cmbs}$, is clear to abrupt. The underlying $2 \mathrm{~B} 2 \mathrm{k}$ horizon consists of massive, carbonate rich loam that is variably cemented, possibly as a result of differences in moisture content. The uncemented areas are dark yellowish brown (10YR 414) and friable, while cemented areas are light yellowish brown (10YR 6/4), hard, and brittle. The entire matrix is violently calcareous. 


\section{Discussion of Site Stratigraphy}

Site 41DW269 is situated on a Holocene terrace overlooking Clear Creek. Several Holocene alluvial fills are present in the vicinity. Unit 1 , which is exposed at depth in the cut bank on the south side of the stream and in BT 2 and BT 3, represents the oldest observed fill in the study area. It forms the core of the higher (T2) terrace and underlies the site at depth. The oldest archeological deposits observed at the site occur in association with Unit 1 . Unit 2 consists of a veneer of more recent alluvium up to about $1 \mathrm{~m}$ thick that mantles Unit 1 on the south side of the stream. It appears to represent occasional overbank sedimentation over an extended period, and contains stratified cultural material in what appears to be relatively good context. Unit 3 consists of sands and sandy loams that underlie the $T_{1}$ surface on the north side of the stream. It is likely that at least some of the alluvial drape making up Unit 2 was deposited during the same period that Unit 3 was aggrading. No cultural materials were noted in association with Unit 3. Unit 4 consists of sands and muds on the channel and narrow modem floodplain.

Unit 1 varies from fine sandy loam and sandy clay loam to silty loam, and is suffused with carbonate that typically takes the form of large concretions, rhizoliths, and/or localized areas of irregular matrix cementation. Based on cultural materials recovered from the matrix and a conventional radiocarbon age of $7450 \pm 70 \mathrm{BP}$ on a snail shell from $150 \mathrm{~cm}$ bgs in TU 2, this fill appears to be of early Holocene age. However, the degree of carbonate development is anomalously strong relative to fills of similar age elsewhere in central and south-central Texas (e.g., Blum 1992; Nordt 1992). This probably reflects the mode of carbonate accretion, which appears related to periodic saturation with carbonate-charged soil water and ground water. As a result of this carbonatecharged water, large carbonate-cemented masses have developed in places in the unit. These concretions vary from relatively small to large nodules $(<0.5 \mathrm{~cm}$ to approx. $3 \mathrm{~cm}$ diameter) and relatively small to large rhizoliths (with lengths ranging from $2 \mathrm{~cm}$ to more than 8 $\mathrm{cm}$ and widths ranging from $<0.5 \mathrm{~cm}$ to $>2 \mathrm{~cm}$ ). Many of the nodules and all of the rhizoliths typically exhibit hollow, brecciated interiors made up of relatively smooth, hard carbonate that grade outward into cemented sandy or silty loam matrix that is visually indistinguishable from the surrounding sediment. This indicates that the features grew from the interior, diffusing outward into the matrix, and thus represent precipitation of carbonate around localized and linear nodes. Carbonate precipitation is also pronounced on some of the artifacts recovered from Unit 1, while other artifacts exhibited no appreciable carbonate rind. Carbonate morphology is commonly used as qualitative evidence of soil development and age, following a model of morphologic stages of pedogenic carbonate development that has developed over the last three decades (e.g., Gile et al. 1966; Gile et al. 1981; Birkeland 1984; Machette 1985). However, while this model is often applicable to mildly semiarid environments such as DeWitt County, the morphological stages are difficult to reconcile with the character of carbonate at 41DW269, and the general model appears to be of little use at the site. Rather, most of the carbonate masses that suffuse the matrix are more properly characterized as pedodes and subcutanic features (Freytet and Plaziat 1978; 1982), and represent carbonate pedofeatures formed under a hydromorphic regime. As such, they have little temporal relevance, because such features can and do develop quite rapidly.

Hydromorphic carbonates are largely ignored in North American literature, but are occasionally addressed in Europe (e.g., Freytet and Plaziat 1978; 1982). Unfortunately, the genetic mechanisms involved remain poorly understood. Carbonate solubility is strongly affected by the partial pressure of dissolved $\mathrm{C}_{2}$, which can be 10 to 100 times the concentration in soil air as in the surrounding atmosphere due to root respiration (Birkeland 1984). In a freely-drained soil, carbonate precipitation is inhibited in the root zone, where the high partial pressure of $\mathrm{C}_{2}$ promotes solubility. However, under saturated conditions, removal of carbonateenriched water by the root systems appears to cause local precipitation of carbonate around roots. While the development of a hard, nearly impermeable coat around the root would seem to inhibit the uptake of water and nutrients, it appears that continued respiration and water withdrawal by the root may promote repeated dissolution and reprecipitation of carbonate in the interior of the features, maintaining the hollow center and allowing the root to continue functioning. The concentration of carbonate around discrete, subvertically-oriented linear features in the matrix at 41DW269 strongly implies that the elongate features are true rhizoliths (i.e., features precipitated around root passages). The concentration of carbonate cements around point sources (nodules and concretions) and certain artifacts (particularly the bone) suggests that other chemical mechanisms are also at work. Therefore, while the character of carbonate development in the matrix of Unit 1 cannot be explained fully without much more research, it is possible to conclude that (1) the carbonate appears to have developed under fluctuating vadose and phreatic 
conditions and should be considered hydromorphic pedogenic phenomena; and (2) the degree and morphology of the carbonate is not a reliable indicator of depositional age.

Unit 2 consists of the veneer of relatively dark loams that form the A and upper B horizon on the $\mathrm{T}_{2}$ terrace. This veneer is approximately $1 \mathrm{~m}$ thick, and appears to have gradually aggraded on the $T_{2}$ terrace as a result of overbank flooding over a period of at least 5,000 years. As a result of concomitant soil development, this unit is typically welded to the underlying fill, so that an erosional bounding surface can rarely be discerned. However, an erosive contact was observed in the profile documented on the modem cutbank. Unit 2 contains the majority of cultural material at the site, and appears to have been deposited by relatively low-energy flows. It is possible that some of the sediment actually represents slopewash shed off the slope at the rear of the terrace, hut most of the material probably represents flood alluvium.

Unit 3 consists of brown sandy loam and sands underlying the sloping $\mathrm{T}$, point bar on the opposite side of the stream. This fill exhibits relatively weak soil development, and, while undated, is probably no more than a few thousand years old. Nevertheless, it is likely that some of the high drape making up Unit 2 was deposited during flood events that occurred during aggradation of Unit 3. Unit 4 consists of sands and muds in the extant channel and floodplain. No in situ prehistoric cultural material is associated with either Unit 3 or Unit 4.

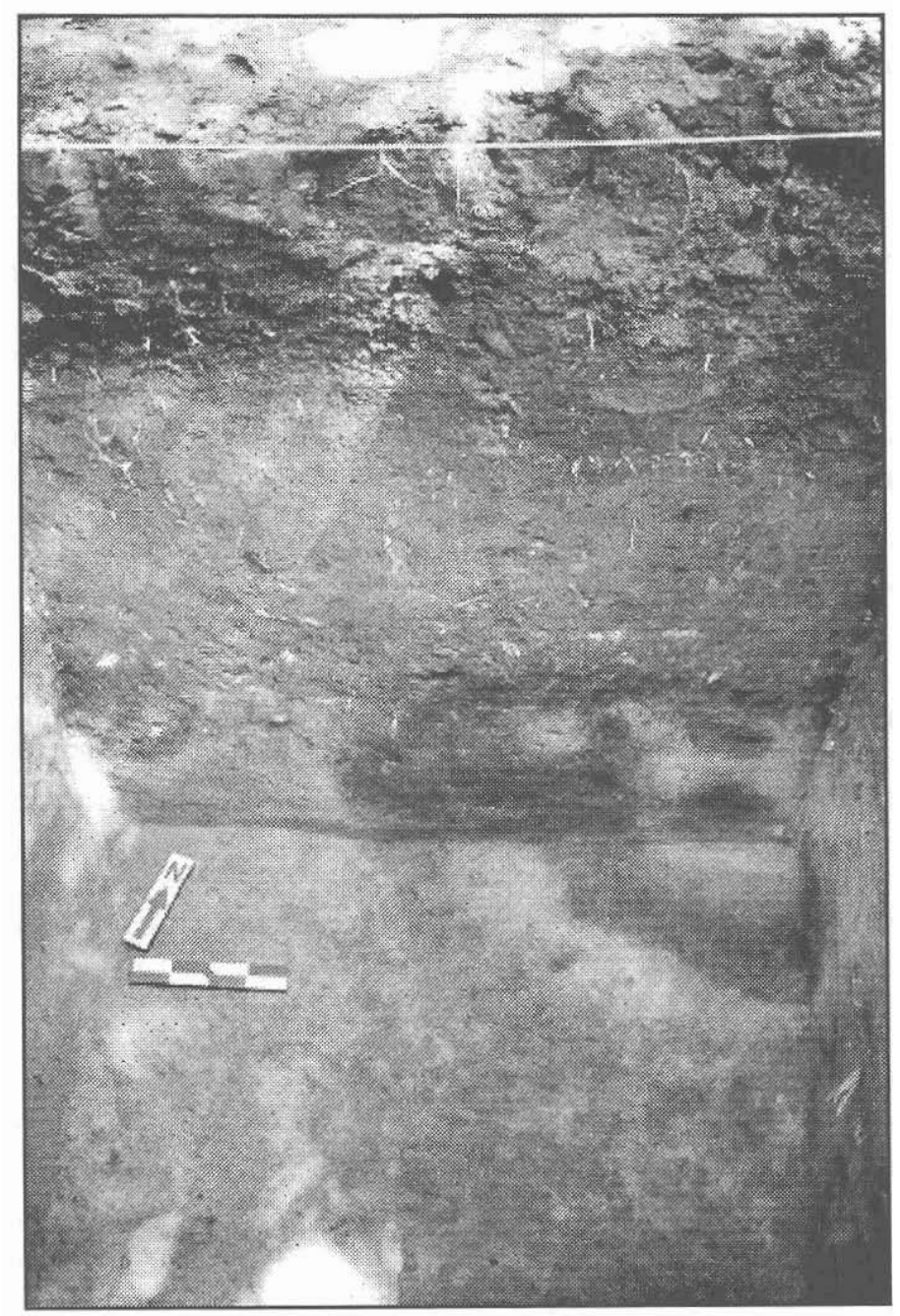

Figure 6: Photograph of the north wall of Test Pit 1. Note the concentric, bullseye-like stain in the floor and the subtle, sloping margin of the pit feature on the left hand side of the wall. 


\section{Test Unit Descriptions}

The following are descriptions of each of the manually excavated test units including locational, matrix, cultural materials and level information. The datum used for elevation control in the test pits was the ground surface at the southeast comer. Since relatively few artifacts were recovered from the site, the artifact inventory and analysis is presented below in context with the matrix and level descriptions of each test pit.

\section{Test UnIT 1}

Test Unit 1 was located approximately one meter south of the bluff face adjacent to the east edge of the proposed right-of-way. Test pit one was placed in on the edge of the to determine the extent and nature of the cultural deposits in that area. The surface of Test Unit 1 was is covered with fallen leaves and humus.

\section{LEVEL 1 (0-10 CM)}

The upper five centimeters of Level $1(0-10 \mathrm{~cm})$ consisted of disturbed materials associated with organic deposits and root activity. The lower five centimeters of Level 1 consisted of a dark black-brown silty loam. No cultural materials were recovered from level one.

\section{LEVEL 2 (10-20 cm)}

The matrix of Level 2 was contiguous with Level 1, dark black-brown silty clay loam with few gravels. The cultural materials of Level 2 consisted of one tertiary flake, one piece of thermal shatter and four rabdotus shells.

\section{LEVEL 3 (20-30 cM)}

The soil matrix in Level 3 was contiguous with the previous levels. The cultural materials in Level 3 consisted of a one tested cobble and three secondary flakes and eight rabdotus shells. The burned rocks were discarded.

\section{LeVEL 4 (30-40 CM)}

The matrix of Level 4 was contiguous with the previous three levels. A soil change occurred at the botom of the level where the matrix became lighter brown in color and finer in texture. The cultural materials in Level 4 consisted of one sandstone metate fragment, one cylindrical hammer stone fragment of petrified wood, one core fragment, 10 secondary flakes, three edge modified secondary flakes, 13 tertiary flakes, one edge modified tertiary flake, 15 decorticate chips, three incised bone fragments (which proved to refit with fragments from Levels 8 and 11), 17 bone fragments, two marine shell fragments, 25 rabdotus shells and 395.5 grams of small burned rocks.

\section{LeVEL 5 (40-50 см)}

The matrix of Level 5 is contiguous with the previous level. The cultural materials in Level 5 consisted of one sandstone metate fragment, one cylindrical hammer stone fragment of petrified wood, one tested cobble, one exhausted core fragment, one primary flake, five secondary flake, one edge modified secondary flake, 18 tertiary flakes, seven corticate chips, 17 bone fragments, 20 rabdotus shells and 309 grams of small burned rocks.

\section{LEVEL 6 (50-60 cM)}

The matrix of level 6 slightly lighter brown that the previous level. The texture of the soil is consistent with the previous level. There was a noticeable increase in cultural materials in this level. The cultural materials in level 6 consisted of a biface (possible pre-form Guadalupe gouge), one exhausted core fragment, 12 secondary flakes, two edge modified secondary flakes, 54 tertiary flakes, 36 decorticate chips, 59 pieces of thermal shatter, 656.5 grams of small bumed rocks and 64 rabdotus shells.

\section{LEVEL 7 (60-70 cM)}

The matrix of Level 7 was noticeably lighter in color and finer in texture than in the previous level. Cultural materials in Level 7 consisted of one sandstone metate fragment, two hammer stone fragments, one exhausted core fragment, one primary flake, 29 tertiary flakes, one edge modified tertiary flake, eight corticate chips, nine decorticate chips, nine pieces of thermal shatter, 963 grams of small burned rocks, and 35 rabdotus shells.

\section{LEVEL 8 (70-80 cm)}

The matrix of Level 8 became progressively lighter, representing the transition from Unit 1 to Unit 2. The matrix was a fine light yellow-brown clay loam with minor carbonate inclusions. An irregular dark brown stain was noticeable in the northeast comer of the unit. It was associated with patches of a fine whitish silty patches which felt ashy. The largest of the white patches was contained partially within the matrix of the stain. The remaining patches were scattered throughout the unit. The dark stain continued some specks of carbon as did some of the surrounding matrix and was designated as Feature 1. The largest white patch was collected for 
analysis. No cultural materials were found in the dark stain. The cultural materials in Level 8 consisted of two pieces of burned bone which restored with those of level 4 , six sandstone mano fragments, three hammer stone fragments, three primary flakes, seven secondary flakes, 17 tertiary flakes, one edge modified tertiary flake, seven corticate chips, six decorticate chips, 13 pieces of thermal shatter, 603 grams of small burned rocks, five mussel shell fragments and 108 rabdotus shells.

\section{LEVEL 9 (80-90 см)}

The matrix of this level was contiguous with the previous level. The dark stain of Feature 1 continued downward to $85 \mathrm{~cm}$ below the ground surface where the soil matrix became uniform across the unit. In the northern profile of the test pit, however, a faint stain became visible which extended upwards from the bottom of Feature 1 to a depth of $35 \mathrm{~cm}$ below the ground surface. The whitish patches in the unit at the end of the previous level proved to be lying on a level paleosurfaces and were approximately $1 \mathrm{~cm}$ thick. The cultural materials in Level 9 consisted of three secondary flakes, seven tertiary flakes, one edge modified tertiary flake, three corticate chips, five decorticate chips, three mussle shell fragments, 160 grams of small burned rocks and 45 rababtus shells.

\section{LEVELO (90-100 CM)}

The matrix of Level 10 was contiguious with the previous level but became slightly lighter in color and finer. An increase in reduction flakes and burned bone was noted during excavation of the Level 10. Cultural materials in Level 10 consisted of one sandstone metate fragment, one exhausted core fragment, four primary flakes, 10 secondary flakes, one edge modified secondary, flake, 49 tertiary flakes, one edge modified tertiary flake, 13 corticate chips, 35 decorticate chips, 11 pieces of thermal shatter, 146.5 grams of small burned rocks, 52 bone fragments and 45 rabdotus shells.

\section{LEVEL 11 (100-110 CM)}

Within the first five centimeters of excavation of Level 11 the soil became mottled in the northeast comer of the test pit with darker brown soil. When the area was troweled, it became apparent that another stain was present directly below the previous stain of Feature 1. Unlike the previous stain in this comer of the test pit, the stain in level 10 had a well defined configuration. When the stain was cleaned off, a semi-circular configuration with concentric bands of alternating dark brown and light yellow-brown soils was clearly visible. Although not noted in the field, photographs of the north profile of Test Pit 1 show the outline of a pit-like feature extending from the bottom of level 3 to the base of the test pit in the northwest comer of the unit (Figure 6). The cultural materials in the lower $5 \mathrm{~cm}$ of level 11 were collected as those from inside the stain (Feature 1) and those from outside of the stain. The cultural materials from Level 11 excluding those from the lower five centimeters of Feature 1 consisted of one medial section of a thin biface, one sandstone metate fragment, one hammer stone fragment, five secondary flakes, 43 tertiary flakes, two corticate chips, 25 decorticate chips, six pieces of thermal shatter, 67.5 grams of small burned rocks and 25 bone fragments. Some of the bone fragments, which were found in situ outside of feature one at an elevation of $110 \mathrm{~cm}$ below the ground surface, restore with those of the incised bone from Levels 8 and 4 . The cultural materials recovered from the lower five centimeters inside Feature 1 consisted of four tertiary flakes, five decorticate chips, and three mussel shell fragments.

\section{Description of Feature 1}

Although a potential feature was recognized in Level 6 of Test Unit 1, the stain observed disappeared within a few centimeters of excavation. While the subsequent levels of the test unit produced patches of whitish material in various locations, mottling in the northeast comer, and occasional specks of charcoal, the outline of the pit was unrecognizable until Level 9 had been completed. Within the first two centimeters of Level 9 a small (approximately $12 \mathrm{~cm}$ diameter) area of burned rocks in a noticeably dark soil was encountered along the north central area of the test unit. Within the fragmented burned rocks was a $5 \times 3 \mathrm{~cm}$ piece of burned chert, bone fragments, and three small pieces of charcoal. The stain occupied the northeast $25 \%$ of the test unit. When seen from above, the dark stain and outlining ring appeared to be a pit. Feature 1 is associated with small bone fragments, specks of carbon and a small burned. It was the impression of the excavator that the stain was not a natural formation such as a krotovina. The photographs of the north profile of Test Unit 1 clearly show the outline of a pit-like feature extending from the approximately $40 \mathrm{~cm}$ below the ground surface to the bottom of the test unit (see Figure 6). This outline was not clearly visible to the eye in the field, and the nature and function of the pit feature remains undefined. However, it appears that approximately 75 percent of the feature remains intact for future investigation.

\section{Test UnIT 2}

Test Unit 2 was located in Mechanical Trench 2 on a safety bench in the northwest comer of the trench. The purpose of Test Pit 2 was to determine the extent and the 
nature of the lower cultural stratum at the site. The first level of Test Pit 2 was begun at an elevation of $110 \mathrm{~cm}$ below the ground surface. The upper $110 \mathrm{~cm}$ of soil which was removed by the backhoe was culturally sterile.

\section{LEVEL 1 (110-120 C M )}

The matrix of Level 1 consisted of a fine, light yellow-brown, silty clay loam with an abundance of calcium carbonate nodules. The matrix of this level was continued through the remainder of the levels excavated. The cultural materials of Level 1 two decorticate chips, 31 grams of burned rocks and three bone fragments.

\section{LEVEL 2 (120-130 сM)}

The matrix of Level 2 is contiguous with Level 1, The autural materials of Level 2 consisted of 50 grams of burned rocks, four bone fragments, and three rubdotus shells.

\section{LEVEL 3 (130-140 CM)}

The matrix of Level 3 is contiguous with the previous two levels, The cultural materials of Level 3 consisted of one piece of thermal shatter and five bone fragments.

\section{LEVEL 4 (140-150 CM)}

The matrix of Level 4 was contiguous with the previous levels. The cultural materials of Level 4 consisted one carbonate encrusted Guadalupe-Like Gouge of petrified wood, two secondary flakes, one corticate chip and one decorticate chip.

\section{LEVEL 5 (150-160 CM)}

The matrix of Level 5 was contiguous with the previous two levels. The cultural materials in Level 5 consisted on exhausted core fragment, two tertiary flakes and 13 bone fragments with heavy carbonate encrustations.

\section{LEVEL 6 (160-170 CM)}

The matrix of level 6 was contiguous with the previous levels. The cultural materials in level 6 consisted of three rabdotus snails.

\section{LeVel 7 (170-180 CM)}

The matrix of level 6 was contiguous with the previous levels. The cultural materials in level 7 consisted of one secondary flake, one tertiary flake, two pieces of thermal shatter 121 grams of burned rocks and 12 rabdotus snails.

\section{LEVEL 8 (180-190 cM)}

The excavation area of Level 8 was reduced to 50 $\mathrm{cm}$ square area in the southeast comer of the test pit. The matrix of Level 8 was contiguous with the previous levels. No cultural materials were recovered from Level 8.

\section{Shovel Test 1}

Shovel Test 1 was located two meters west and one meters south of Test Unit 1 . Shovel Test Pit 1 was intended to further determine extent of the cultural deposits at site. The surface of TP 1 was is covered with fallen leaves and humus.

\section{LEVEL 1 (0-10 CM)}

The upper five centimeters of Level $1(0-10 \mathrm{~cm})$ consisted of disturbed materials associated with organic deposits ant root activity. The lower five centimeters of Level 1 consisted of a dark black-brown silty loam. No cultural materials were recovered from level one.

\section{LEVEL 2 (10-20 CM)}

The matrix of Level 2 was contiguous with Level 1, dark black-brown silty clay loam with few gravels. No cultural materials were recovered from level two.

\section{LEVEL 3 (20-30 CM)}

The soil in level was contiguous with the previous levels. The cultural materials in level three consisted of an edge modified secondary flake, one secondary flake, two tertiary flakes and one decorticate chip.

\section{LEVEL 4 (30-40 CM)}

The matrix of Level 4 was contiguous with the previous three levels. A soil change occurred at the bottom of the level where the matrix became lighter brown in color and finer in texture and corresponds with the soil change that occurred in Test Unit 1 at the same elevation. No cultural materials were recovered from level four.

\section{LEVEL 5 (40-50 CM)}

The matrix of Level 5 is contiguous with the previous level. The cultural materials in Level 5 consisted of one lateral edge of a thin biface, 2 secondary flake, 2 tertiary flakes, one piece of thermal shatter, 1 bone, 1 rabdotus shell and 272 grams of small burned rocks.

\section{LEVEL 6 (50-60 CM)}

The matrix of level 6 slightly lighter brown that the previous level. The texture of the soil is consistent with the previous level. The cultural materials in level 6 consisted of two primary flakes, 2 secondary flakes, 2 
tertiary flakes, 2 corticate chips, 2 decorticate chips, 2 pieces of thermal shatter, 347.5 grams of small burned rocks, 7 mussel shell fragments, 1 small fragment of red ochre and 21 rabdotus shells.

\section{LEVEL 7 (60-70 CM)}

The matrix of level 6 slightly lighter brown that the previous level. The texture of the soil is consistent with the previous level. in Level 7 consisted of one secondary flake, one tertiary flake, one edge modified tertiary flake, two pieces of thermal shatter, 121 grams of small burned rocks and 12 rabdotus shells.

\section{LEVEL 8 (70-80 С $)$}

The matrix of Level 8 became slightly lighter and more yellowish but remained predominately reddishbrown in color. There was a slight increase in the amount of gravels which composed approximately $2 \%$ of the matrix. Cultural materials in Level 8 consisted of one secondary flake, two tertiary flakes, 80 grams of small burned rocks and 13 rabdotus shells.

\section{LEVEL 9 (80-90 CM)}

The matrix of this level was contiguous with the previous level. The cultural materials in Level 9 one decorticate chip, four decorticate chips, 30.5 grams of small burned rocks and 11 rabdotus shells.

\section{LEVEL 10 (90-100 CM)}

The matrix in Level 10 was contiguous with the previous level. The cultural materials in Level 10 consisted one decorticate chip and 92.5 grams of small burned rocks, one bone fragment and 4 rabdotus shells.

\section{Shovel Test 2}

Shovel Test 2 was located two meters west and five meters south of Test Unit 1. Shovel Test 2 was intended to further determine extent of the cultural deposits at site to help determine the southern extent of the upper cultural strata an the site. The surface of Shovel Test 2 was is covered with fallen leaves and humates.

\section{LEVEL 1 (0-10 CM)}

The upper five centimeters of Level $1(0-10 \mathrm{~cm})$ consisted of disturbed materials associated with organic deposits ant root activity. The lower five centimeters of Level 1 consisted of a dark black-brown silty loam. No cultural materials were recovered from level one. Level 2 $(10-20 \mathrm{~cm})$ The matrix of Level 2 was contiguous with Level 1, dark black-brown silty clay loam with few gravels. No cultural materials were recovered from level two.

\section{LEVEL 3 (20-30 CM)}

The soil in level was contiguous with the previous levels. The cultural materials in Level 3 consisted of one secondary flake, one tertiary flake, one decorticate chip, two pieces of thermal shatter and 24.5 grams of small burned rocks.

\section{LEVEL 4 (30-40 CM)}

The matrix of Level 4 was contiguous with the previous three levels. A soil change occurred at the bottom of the level where the matrix became lighter brown in color and finer in texture and corresponds with the soil change that occurred in Test Unit land Shovel Test 1 at the same elevation. The cultural materials in Level 4 consisted of one secondary flake, one edge modified tertiary flake of petrified palm, one tertiary flake, one decorticate chip, two pieces of thermal shatter, two bone fragments, 1 rabdotus shell and 61.5 grams of small burned rocks.

\section{LEVEL 5 (40-50 CM)}

The matrix of Level 5 was contiguous with the previous three levels. The cultural materials in Level 5 consisted of two secondary flakes, one decorticate chip, two pieces of thermal shatter and 12.5 grams of small burned rocks. 


\section{Results of Auger Testing}

Three different deposits were noted in the nine auger holes excavated in the revised CR 122 bridge abutment footprint (Figure 7). The oldest deposit consists of a massive, grayish brown to brown (10YR5/2 to 10Y R 5/ 3 ) silty loam that represents the lower alluvial stratigraphic unit (Unit 1). Unit 1 was encountered in five auger tests (AH 4, 5, 6, 7, and 8). Secondary carbonate forms were absent in two of those test borings (AH 4 and AH 5), while large nodules and rhizoconcretions were present in the other three (AH 6, 7 and 8). This increase in carbonate content and morphology is believed to relate to differences in diagenetic and pedogenic processes operating near the stream cutbank and away from it. Despite the very different character of carbonate development, the color and texture of the sediment is distinctive and clearly represents a single depositional unit.

The second deposit observed in the nine auger tests consists of a weak blocky structured, dark grayish brown (10YR 4/2) clay loam containing common carbonate filaments and a few small, hard carbonate nodules. This deposit was observed in $\mathrm{AH} 2$ and $\mathrm{AH}$ 3. It appears to correlate with the late Holocene drape noted on the site (Unit 2). In addition, a clayey, dark alluvial unit was also observed at depth in AH 9. This deposit appears to represent the A and $\mathrm{Bw}$ horizon of Unit 2, which is buried beneath approximately $50 \mathrm{~cm}$ of stratified historic fill.

The third deposit consists of a variety of artificial fill sediments introduced in the process of road construction. These sediments include stony dark clay loam which may represent an admixture of siliceous fill gravels and reworked local clay loam sediment, a buff to tan clayey fill representing caliche road base, and a brown sandy loam fill that represents introduced fill. This latter sediment makes up the majority of the profile revealed behind the extant bridge support (AH 1), suggesting that the concrete support was poured and then filled in from behind. Moving away from fill behind the current bridge, the first auger tests (AH 2 and 3) encountered dark gray clay loam sediments interpreted as Unit 2. Next, sediments interpreted as Unit 1, but lacking in strong carbonate development, were encountered in AH 4 and 5. More typical Unit 1 sediments were then encountered in $\mathrm{AH} 6,7$, and 8 . This pattern suggests that the original surface was sloping, and that the Unit 2 fill was inset against the lower fill. The discovery of probable Unit 2 sediments at depth in AH 9 suggests that the terrace was also beveled towards the gully to the west prior to filling and road construction. 


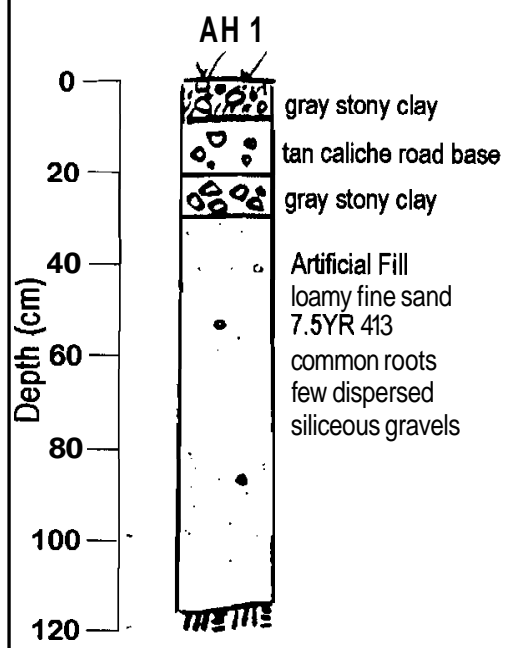

AH 4

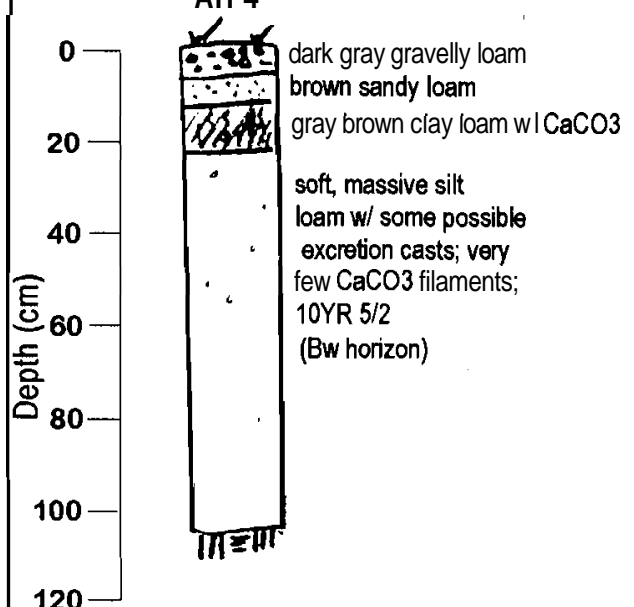

AH 7

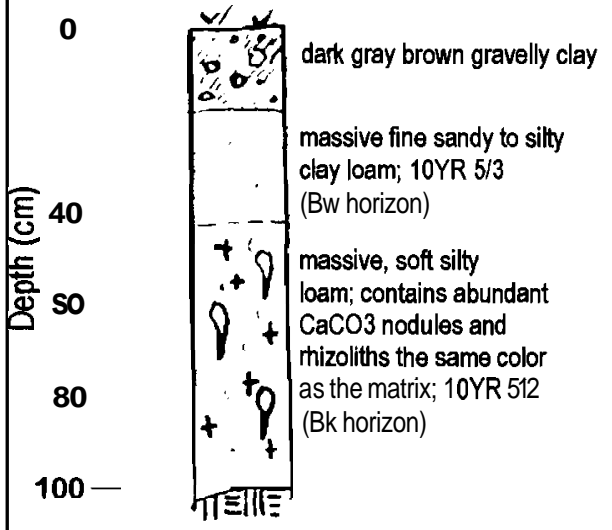

AH 2

o," :- stratifiedgray stony

common $\mathrm{CaCO} 3$

filaments and small hard nodules

( 1OYR 4/2

(Bk horizon)

11

三1

AH 5

aravelly loam

gravelly clay loam

iring gravelly clay loam

.

soft, massive silt

loam wl some possible excretion casts; very

few $\mathrm{CaCO} 3$ filaments;

10YR 512

(Bw horizon)

$-$

(Bw hoizon)

AH 8

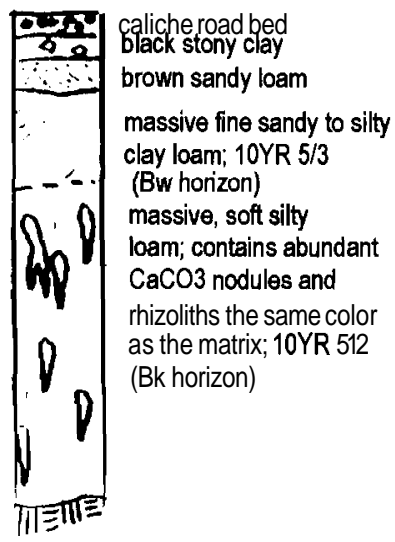

AH 3

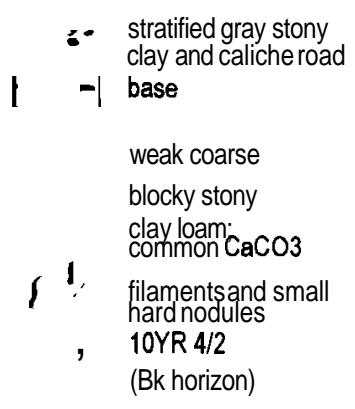

1,

II

\section{AH 6}

... gravelly clay

brown sandy loam

$+\quad$ sofl, massive silt loam wl some possible excretion casts; common large, hard $\mathrm{CaCO} 3$ nodulesand occasional

+ r. rizolithsthat are the same color as the matrix 10YR 5/2

++ (Bk horizon)

$+$

AH 9

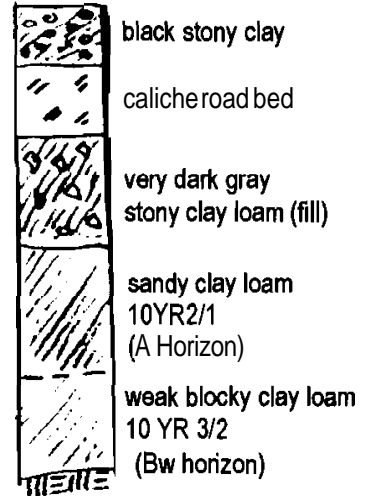

Figure 7: Schematic profiles of the nine auger holes excavated at 41DW269. 


\section{Discussion of Cultural Materials}

A total of 845 artifacts (excluding burned rock and snail shells) were collected from the two manual excavation units, two shovel tests, surface and cutbank at 41DW269. The majority of the artifacts recovered from the site $(\mathrm{n}=599)$ are lithic debitage, which comprise 70.89 percent of the collection. The second greatest quantity of artifacts recovered at 41DW269 $(\mathrm{n}=138)$ are faunal remains, which comprise 16.41 percent of the collection. The remaining number of artifacts recovered $(\mathrm{n}=10)$, include all remaining categories and comprise 12.70 percent of the collection. Diagnostic and other distinctive artifacts collected from the surface and cutbank are illustrated in Figure 8, and those from the excavation are illustrated in Figure 9.

\section{Projectile Points}

All of the temporally diagnostic artifacts, with the exception of the Guadalupe-like gouge recovered from Test Unit 2 (Figure 9a) and the possible Guadalupe preform from Test Pit 1 (Figure 9b), were found during surface collection or inspection of the bluff face and are manufactured from siliceous cherts. During the preliminary survey one poorly preserved and heavily burned proximal fragment of an unidentifiable projectile was found on the surface. The proximal fragment is likely of Late Archaic origin. Two projectiles were recovered in the erosional spoil at the toe of the cutbank face. These two specimens are Morhiss and Lange-like projectiles. The Morhiss point is nearly $1.0 \mathrm{~cm}$ thick and heavily reworked (Figure 8a). This lanceolate projectile has square shoulders, the proximal end is fractured below the shoulders and distal tip is also fractured. The fractures on both ends of the Morhiss projectile appear to be the result of impacts. The distal and proximal ends of the projectile bear evidence of post impact/fractureresharpening. One lateral edge and the distal end are bifacially re-sharpened resulting in a steep, nearly rounded, blade angle. The other lateral edge is unifacially reworked into a shallow angled, sharp edged, blade. The classification of the Lange-like projectile is more problematic. This specimen has a short triangular body with straight to slightly convex lateral edges and square to slightly barbed shoulders (Figure 8b). One of the shoulders is missing. The narrow stem of the Langelike projectile is thick, slightly expanding and has slightly convex lateral edges which are smoothed. The base of the stem is missing as a result of a snap fracture. However, enough of the base is preserved to determine that it was thinned. Not enough of the projectile was preserved to determine if the specimen was basal notched. Because the edges of the base are thicker at the fracture point than at the center and the stem appears to continue expanding beyond the fracture point, it can be inferred that the projectile had expanding ears of at least 2.0 to $3.0 \mathrm{~mm}$ in length. The blade of the projectile has been reworked with numerous fine pressure flake removal and is markedly beveled. The beveling may, however, be the result of the manufacturer's attempts to compensate for a large stack that developed in the blade face during the reduction process. Whether the base of the projectile was notched or merely thinned is significant in the temporal interpretation of the artifact. Because of the smoothing on the stem edges, fine pressure flaking and the strong possibility of basal notching, one is inclined to assign the specimen to an Early Archaic affiliation, as with the Uvalde type, rather than a Late Archaic affiliation, as with the Lange type. For the purpose of this discussion, however, the projectile was found in a surficial context and assigning the specimen to the broader category of "Archaic" is sufficient. The third projectile was found on the surface at the eastern edge of the site. This asymmetrical lanceolate projectile (Figure 8c) is nearly $1.0 \mathrm{~cm}$ thick and is mostly intact with the exception of the distal tip which has been snapped off. The lateral edges of this specimen are steep and exhibit only minor evidence retouch. The asymmetry of the point may be attributed to flaws encountered within the chert during the reduction process. The base of the contracting stem of the projectile has been thinned through the removal of several fine pressure flakes. This projectile is typologically closest to Lerma or Refugio forms and can also be assigned an Archaic cultural affiliation. A fourth untyped projectile fragment was found eroding from the bluff face at the approximate center of the exposure. This specimen (Figure 8e) was found together with a small quartzite hammer stone in a clear stratigraphic context at a depth of $70 \mathrm{~cm}$ below the natural ground surface, just below the boundary between the A and $\mathrm{B}$ soil horizons. Both the projectile fragment and the accompanying hammer stone were heavily encrusted with fibrous calcium carbonates. The fragment is the proximal end of a $1.0 \mathrm{~cm}$ thick biface with a nearly flat to slightly concave base. The base has been moderately thinned and smoothed. The lateral edges are also moderately smoothed. It is not clear whether the basal and edge smoothing was done as edge preparation for further reduction or as preparation for halfting. 


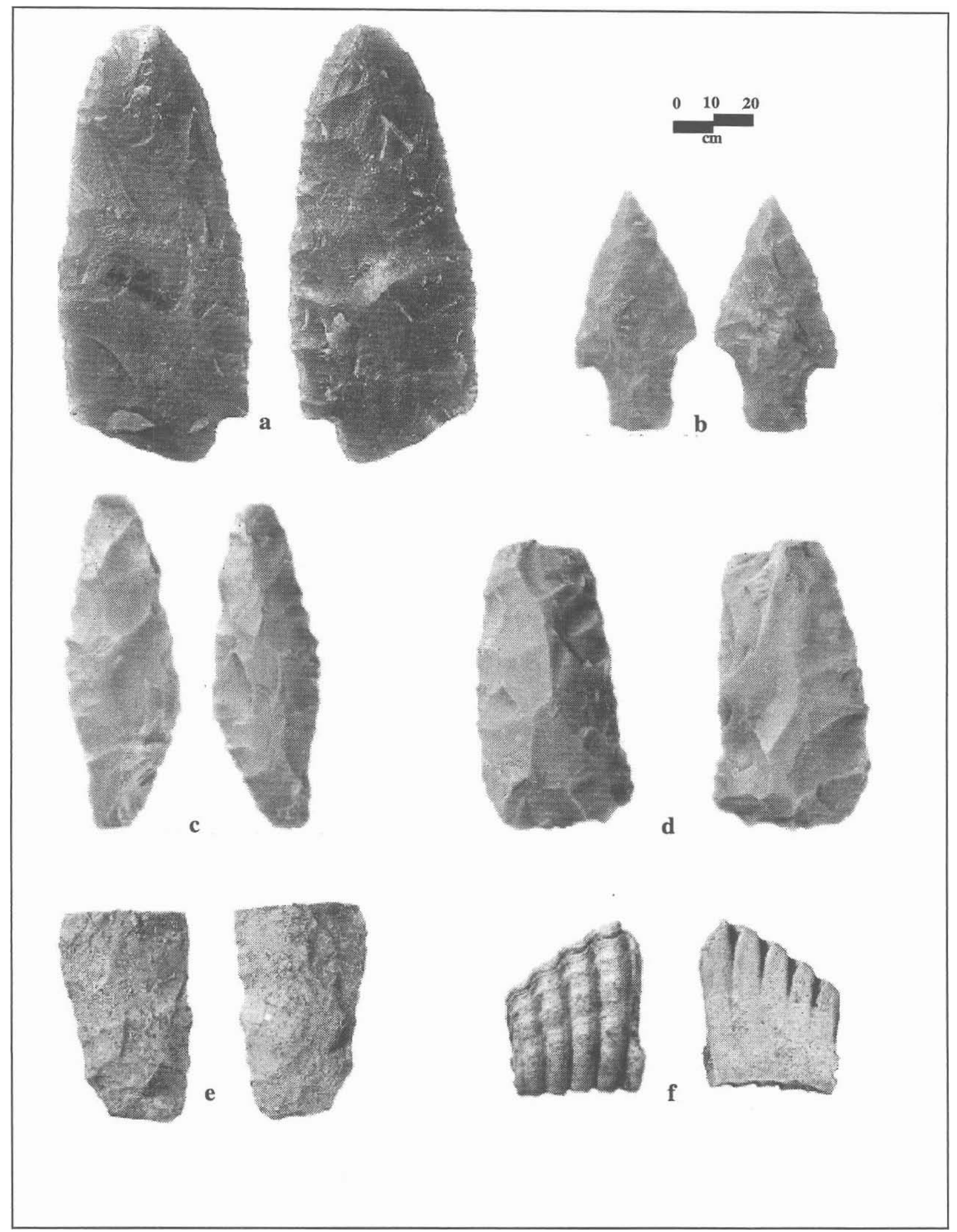

Figure 8. Diagnostic and other distinctive artifacts from surface and cutbank contexts: a) Morhiss; b)Lange-like; c) Thin Biface; d) Thin Biface Proximal End; e) Scraper/G ouger; f) Marine shell. 


\section{BIFACES}

Three other temporally diagnostic distally beveled bifaces were recovered from the present testing efforts at 41DW269. The first of these three artifacts is a small, thick, rectangular, bifacial gouge that was found on the surface during the initial survey (Figure 8d). This distally beveled tool is similar to those represented in Group 4 recovered at Loma Sandia, 41LK28 (Taylor and Highly 1995:470). Taylor and Highly report that similar gouges were also found at Choke Canyon. The specimen found at 41DW269 has a nearly flat to slightly convex ventral surface and a dorsal surface that is triangular in cross section with a prominent medial ridge. The bit is relatively flat and the proximal end is rounded with partial cortex. The lateral edges of the proximal $b$ of the gouge have been smoothed. It is unclear whether the bit exhibits evidence of use wear. It is noteworthy that six of the ten specimens from Loma Sandia of this type were recovered from human burials in Middle to Late Archaic contexts. The second distally beveled biface was found in the bottom of Level 6 at $60 \mathrm{~cm}$ below the ground surface in Test Unit 1 (Figure 9b) This specimen is thicker, longer and more narrow that the previously described gouge. The ventral surface of this gouge is rounded to nearly flat and the dorsal surface is thick, triangular in cross section, has a prominent medial ridge, and is thickest towards the distal end. Both the distal and proximal ends have remnants of cortex. There is some evidence of smoothing on the lateral edges of the proximal end. The bit has a convex edge The most notable attribute of this specimen is the large manufacturing error that resulted in the removal of an unexpectedly large flake from the ventral surface. Subsequent flake removal from the area of the error indicate an attempt to compensate for the flaw. There is some possible use wear in on the working surface of the bit. However, because of the manufacturing error and the presence of the cortex on both ends of the gouge, it is not clear whether the implement was a reject or a finished product. This gouge is comparable to Group 1 distally beveled tools at Loma Sandia. The specimens of this type are classified as Clear Fork tools at Loma Sandia and were surface collected (Taylor and Highly 1995: 466-67). The specimen from 41DW269 exhibits more attributes of Guadalupe tools than its Clear Fork counterpart and typologically falls between the two classification groups. This specimen was found in association with a pit (Feature 1) in Test Unit 1. The function of the pit in Test Unit 1, which spans nearly the entire vertical depth of the Unit and intrudes into the underlying B Horizon, is uncertain. Contextual evidence suggests that Feature 1 is likely of Late Archaic age. The third distally beveled biface is a $2.0 \mathrm{~cm}$ thick, triangular Guadalupe tool manufactured from silicified wood. The gouge is $7 \mathrm{~cm}$ in length, is plano-convex in cross section and has a prominent medial ridge (Figure 9a). The broad bit of the gouge is slightly concave and exhibits evidence of heavy use wear. The working surface is formed by the removal of flakes from both the dorsal and ventral surfaces. The primary bit angle is on the ventral side of the tool, which is typical of Guadalupe tools. A large stack is developed just behind the distal end of the dorsal surface, which probably formed as a result of repeated resharpening. The proximal end of the gouge is thin and pointed. The full length of the lateral edges are smoothed. This specimen was found in Test Unit 2, Level 4 at $150 \mathrm{~cm}$ below the ground surface. The gouge was found within Unit 1 in a clear stratigraphic context and in association with a carbonate-fused mass of bone that was subsequently identified as Odocoileus virginianus (white-tailed deer; see Appendix A) and a sparse amount of lithic debitage. The bone mass was found in Level 5 at $155 \mathrm{~cm}$ below the ground surface. Both the gouge and bone mass were heavily encrusted in dense calcium carbonates to such an extent as to be urecognizable. A sample of rabdotus shell from the matrix in the vicinity of the gouge and bone mass was submitted to Beta Analytic, Inc. for radiocarbon assay. The test results yielded a corrected date of $7540 \pm 70 \mathrm{BP}$ which suggest that the deposit containing the bones and gouge dates to the Early Archaic Period. The full results of the radiocarbon analysis are reported below.

\section{Hammer Stones and Ground STONE}

Three small spherical to ovoid chert hammer stones were recovered from 41DW269 in Test Unit 1. These fragmented specimens exhibited minor evidence of wear in the form of pecking scars. A third small ( $4.0 \times 2.5$ $\mathrm{cm}$ ), elongated petrified wood hammer stone fragment was recovered from Level 4 of Test Unit 1 . This fragmented specimen exhibits evidence of smoothing, bashing or pecking on the distal end and possibly served to remove smaller reduction flakes during the knapping process. The specimen also has been smoothed in the medial region, possibly as a result of use wear. Eleven sandstone metate fragments and one mano were recovered from 41DW269. Ten of the metate fragments were recovered from throughout the matrix of Test Unit 1 and are likely fragments of one or more larger specimens. Some small yellow/green metate fragments from different levels were found to restore into larger pieces. Other fragments of courser grained darker sandstone metate fragments in Test Unit 1 were clearly 
not of the same material. One of the metate fragments form the site was recovered from the surface collection. A single quartzite mano/hammerstone was found at 41DW269. The mano was found eroding from the bluff face at $70 \mathrm{~cm}$ below the ground surface at the boundary between the A and B soil horizons. This small, $4.0 \times 5.0$ $\mathrm{x} 3.0 \mathrm{~cm}$, ovoid quartzite mano was found with the proximal end of a lanceolate projectile (Figure 8d) and was encrusted in dense calcium carbonates.

\section{Edge Modified Lithic Debitage}

A total of 18 specimens representing 3.006 percent of the 599 pieces of lithic debitage collected from 41DW269 bare evidence of edge modification. Five of the 18 specimens have clear evidence of use wear in the form of micro flaking and polishing along one or more of the edges. One of these five specimens is a tertiary flake of petrified or silicified palm recovered in Shovel Test 2, Level $4(30-40 \mathrm{~cm})$. The remaining 13 specimens exhibit evidence of micro flaking along one or more edges, but the cause of the edge modification can not be clearly attributed to use wear.

\section{SHELl AND Bone}

Several heavily burned fragments of an incised radius of a White Tail Deer were found in Levels 4 and 11 of Test Unit 1. Fragments of this incised bone were refit (see Appendix A), demonstrating that the fragments are from the same element despite their stratigraphic dispersion. Although some of the fragments were found within the matrix of Feature 1, others were recovered from areas apparently outside of the pit. The incised bone is described in detail in the Appendix A below. The final diagnostic artifact found at 41DW269 was a marine shell fragment found on the surface at the eastern edge of the site (Figure 8f). This shell fragment exhibits evidence of use wear in the form of striations and polishing along the serrated distal edge. This type of use ware is indicative of possible use of the shell as a digging implement. Two other smaller marine shell fragments were recovered from Test Unit 1, Level 4 (30$40 \mathrm{~cm}$ ). Fragments of a similar marine shell were recovered at Choke Canyon (Hall et al. 1986: 335-37). Several fragments of fresh water mussel shells were recovered from the eroded bluff face, Test unit 1 , and Shovel Test 1 . None of the mussel fragments exhibit any form of modification and probably represent subsistence remains. The observed mussel shells fragments were limited to the upper $40 \mathrm{~cm}$ of the site matrix. The bone recovered from 41DW269 is further discussed in the following section.

\section{Faunal Material}

The faunal remains recovered from 41DW269 were submitted to the Center for Archaeological Research, the University of Texas at San Antonio, where they were analyzed by Barbara A. Meissner (Appendix A). In her report, Meissner states that the number of bones recovered from 41DW269 is very low. However, when the excavated volume $(2.55 \mathrm{~m} 2)$ is considered, the yield of faunal remains from the site is a quite respectable 55 items $/ \mathrm{m} 3$ on average. Moreover, 70.5 percent of the all the faunal remains collected at the site were recovered in 1.1 cubic meters of excavated matrix in Test Unit 1 , which equates to a density of nearly 100 items $/ \mathrm{m} 3$ in the upper M iddle/Late Holocene deposit. The ratio of faunal remains to lithic artifacts (excluding shell and burned rock) in Test Unit 1 is $1: 6$, or 15.9 percent of the return. The ratio of faunal remains to lithic artifacts recovered from Test Unit 2 (BHorizon) is 3:1 or 65.1 percent of the return. The ratio of faunal remains to lithic artifacts recovered from Shovel Test 1 is 4:39 or 9.4 percent of the return. The ratio of faunal remains to lithic artifacts recovered from Shovel Test 2 is 2:15 or 11.8 percent of the return.

Meissner's analysis points out several other interesting characteristics of the faunal assemblage. First, the assemblage is relatively diverse, including bison, white-tailed deer, cottontail rabbit, jackrabbit, opossum, turtle, large bird, and rattlesnake, with little evidence of concentration on specific species. Second, the assemblage is indicative of relatively intense processing by humans. Slightly less than $25 \%$ of the sample was identifiable to genus level, largely because much of the material was broken into relatively small pieces. Over half of the bone exhibits evidence of burning, and much of it is calcined, suggesting intense and prolonged heating. Cut marks and green fractures are apparent on approximately $14 \%$ of the assemblage.

\section{Special SAMPLes}

During the excavation of Test Unit 1, two $1.0 \mathrm{~cm}$ thick deposits of flat-lying whitish deposits were encountered in Levels 7 and 8. The patches were dense, compacted and brittle. On first appearance, the material was presumed to be ash and felt silty when rubbed between the fingers. Crystalline calcite and other micro inclusions can be observed within a porous matrix when viewed with a hand lens. A sample of this material was submitted to the Bureau of Economic Geology at the University of Texas at Austin for petrographic analysis. The results of the analysis are presented in Appendix B. 


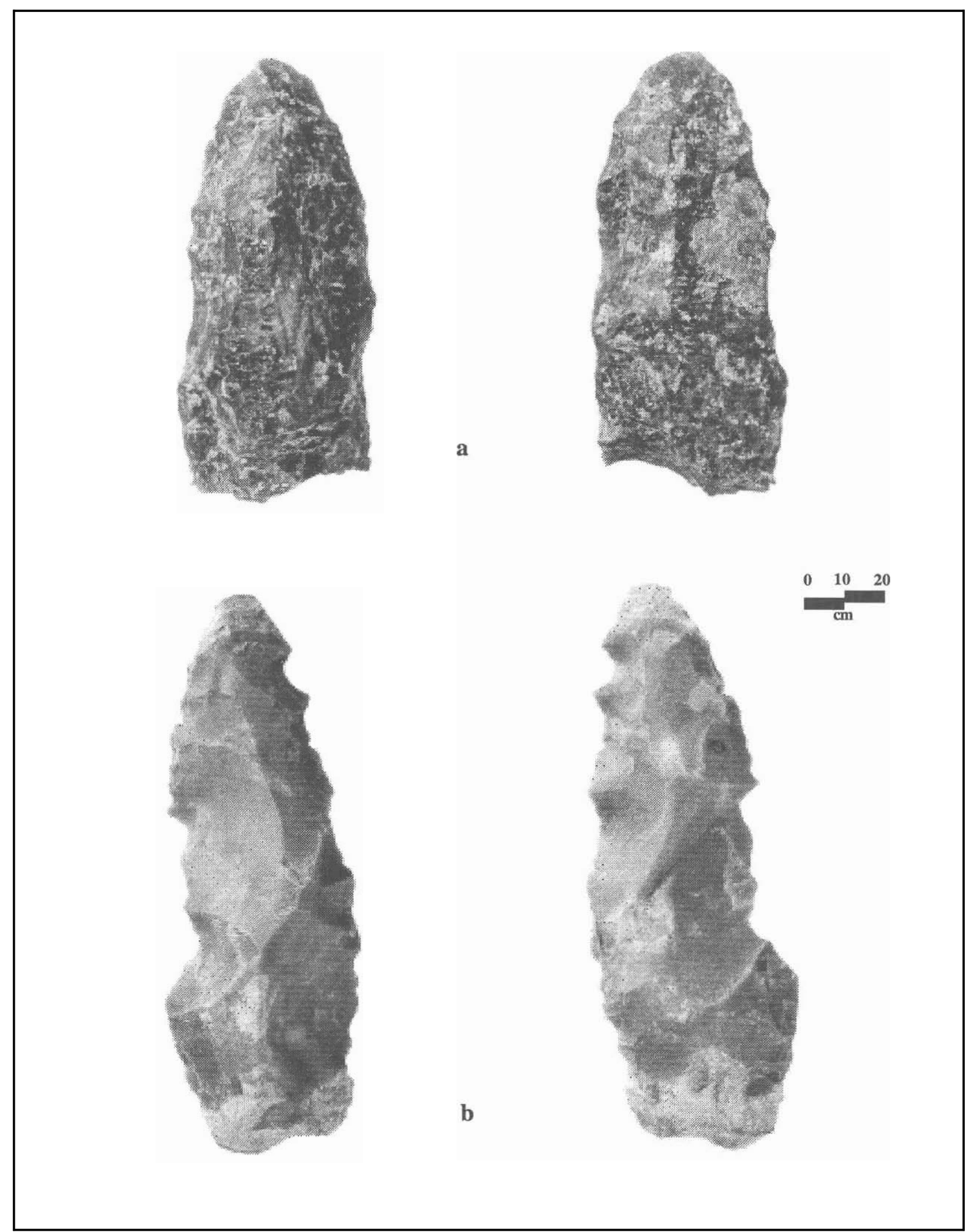

Figure 9. Diagnostic and distinctive artifacts from excavations: a) Guadalupe Gouge; b) possible Guadalupe/ Clearfork Gouge preform. 
Although a clear conclusion was not possible, the analysis indicated that the sample consists of a micritic calcite groundmass with common sand-sized to silt-sized quartz fragments, occasional rock fragments, and areas of amorphous opaque material presumed to represent organic matter. The morphology of these deposits rules out the possibility that they are postdepositional pedogenic phenomena. Each represents a discrete, irregular mass resting on a nearly level paleosurface. Their discrete character and association with the rich cultural stratum suggests that they are prbably of anthropic origin. One possible explanation is that they represent wood ash that was wetted and compacted prior to burial, because wood ash is made up almost entirely of mineral matter such as calcium oxalate, which converts readily to calcium carbonate (Courty et al. 1989; Jones et al. 1997). However, none of the other components (e.g., finely-divided charcoal, phytolith cell casts, etc.) or complex internal stratigraphy (e.g., crosscutting laminations) that could be expected in such deposit were observed in the thin section. Another possibility is that they represent dumps of the gritty "gruel" that collects in the bottom of a container used for stone boiling as the exterior of the boiling stones slough off. This sludge has been observed by one of the authors (Abbott) during stone boiling experiments, but to our knowledge no examination of this material has ever been made.

However, the composition of the deposit in question is consistent with expectations for the sludge produced by stone boiling using a combination of limestone and sandstone clasts. Nevertheless, at this point, the origin of these white deposits remains in question.

A single rabdotus snail from Test Unit 2, level 5 (150-160 cm), was submitted to Beta Analytic, Inc. of Miami, Florida, for ${ }_{14} \mathrm{C}$ analysis. The sample submitted was associated with calcified white tailed deer remains, a Guadalupe tool, and minor quantities of lithic debitage in the carbonate rich Unit 1 fill. The sample yielded a measured 14Cage of $7270 \pm 70 \mathrm{BP}$ with a $8{ }_{13} \mathrm{C}$ ratio of $8.8 \%,{ }^{18} \mathrm{O} /{ }^{16} \mathrm{O}$ ratio $=2.2 \%$. The conventional age measured $7540 \pm 70 \mathrm{BP}$. The calibrated age of the sample was 6460 to $6195 \mathrm{BC}$ at 2 sigma and 6425 to $6245 \mathrm{BC}$ at 1 sigma. The intercept of radiocarbon age with calibration curve is $6385 \mathrm{BC}$. 


\section{Conclusions}

Archaeological investigations within the right-ofway of CR 122 at Clear Creek indicate that the site is a multicomponent site with at least two distinct periods of occupation. The lower occupation is associated with a carbonate-charged alluvial fill that forms the core of the landform, and the upper occupation is associated with a more recent alluvial veneer laid down across the surface. On the basis of temporally diagnostic artifacts recovered from 41DW269, contextual evidence and the results of the radiocarbon testing, the earliest occupation of the site was during the Early Holocene (ca. 8000-6000 BP). Although materials associated with this component are sparse, they appear to have tremendous research value given the scant information available about the Early Archaic on the outer Coastal Plain. The occupation associated with the overlying veneer probably represents a long-term accumulation that formed episodically as the terrace slowly aggraded. It clearly contains material dating to the Late Archaic, and may also contain material dating to the Middle Archaic. The vertical provenience and integrity of materials recovered from the upper assemblage in Test Unit 1 are somewhat questionable due to the presence of a deep prehistoric pit (Feature 1) that cuts through the strata. Nevertheless, the presence of this pit feature does not diminish the research potential of the upper deposit as a whole.

Not enough evidence was found at the site to draw significant conclusions as to the type of occupations and site utilization which occurred at 41DW269 during prehistoric times. However, abundant faunal remains in all of the three cultural strata identified indicate that at least some degree of food processing occurred at site 41DW269 during the all of the periods of occupation. The literature indicates that there is a paucity of sites in the Central Texas Coastal Plains with faunal remains (Tomka et al. 1997). The amount and level of preservation of faunal remains present at site 41DW269 contribute considerably to the research potential of the site, and hence to its significance, since the data it contains have the potential to yield important information related to the study of subsistence patterns in the region. In addition, as stated above, there are very few sites in the Central Texas Coastal Plains with intact components dating to the Early Archaic Period. At site 41DW269 the Early Archaic component is apparently intact, stratigraphically separate and contains preserved faunal materials in context with diagnostic artifacts. The Early Archaic component at site 41DW269 could yield important insights about the subsistence and other activities. In conclusion, it recommended that 41DW269 is eligible for inclusion to the National Register of Historic Places and designation as a State Archeological Landmark. 
Significance Testing at Prehistoric Archeological Site... 


\section{REFERENCES}

Barnes, V. E.

1974 Geologic Atlas of Texas, Seguin Sheet. Bureau of Economic Geology, University of Texas at Austin.

Birkeland, P. W.

1984 Soils and Geomorphology. Oxford University Press, New York.

Blair, W. F.

1950 The biotic provinces of Texas. Texas J ournal of Science 2(1): 93-117.

Blum, M. D.

1992 Modem Depositional Environments and Recent Alluvial History of the Lower Colorado River, Gulf Coastal Plain of Texas. $\mathrm{PhD}$ Dissertation, The University of Texas at Austin.

Collins, M. B.

1995 Forty years of archeology in Central Texas. Bulletin of the Texas Archeological Society 66: 361-400.

Courty, M. A., P. Goldberg, and R. MacPhail. 1989 Soils and Micromorphology in Archaeology. Cambridge: Cambridge University Press.

Fenneman, N. M.

1938 Physiography of the Eastern United States. New York: McGraw Hill.

Freytet, P. and J.-C. Plaziat.

1978 Les redistributions carbonatkes pedogenetiques (nodules, croutes, "calcrete"): les deux types principaux d'environments favorables a leur developpment. Compte Rendue des Seances de 1" A cademiedes Sciences de Paris 286: 1775-1778.
Freytet, P. and J.-C. Plaziat.

1982 Continental Carbonate Sedimentation and Pedogenesis - Late Cretaceous and Early Tertiary of Southern France. Contributions to Sedimentology 12, E. Schweizerbart'sche Verlagbuchhandlung, Stuttgart.

Gile, L. H., J. W. Hawley, and R. B. Grossman.

1981 Soils and Geomorphology in the Basin and Range Area of Southern New Mexico-Guidebook to the Desert Project. Memoir 39, New Mexico Bureau of Mines \& Mineral Resources.

Gile, L. H., F. F. Peterson, and R. B. Grossman.

1966 Morphological and genetic sequences of carbonate accumulation in desert soils. Soil Science 101: 347-360.

Hall, Grant D., S. L. Black and C. Graves.

1982 Archaeological Investigations at Choke Canyon Reservoir, South Texas: The Phase One Findings. Choke Canyon Series, Volume 5. Center for Archaeological Research, The University of Texas at San Antonio.

H al IG. D., T. R. Hester, and S. L. Black.

1986 The Prehistoric Sites at Canyon Reservoir, Southern Texas: Results of Phase II Archaeological Investigations. Choke Canyon Series, Volume 10. Center for Archaeological Research, The University of Texas at San Antonio.

Hester, T. R.

1980 Digging into South Texas Prehistory. San Antonio: Corona Publishing.

1995 The prehistory of South Texas. Bulletin of the Texas Archeological Society 66: 427-459. 
Johnson, L., Jr., and G. T. Goode.

1994 A new try at dating and characterizing Holocene climates, as well as archeological periods, on the eastern Edwards Plateau. Bulletin of the Texas Archeological Society 65: $1-51$.

Jones, T. P., W. G. Chaloner, and T. A. J. Kuhlsbuch.

1977 Proposed bio-geological and chemical based terminology for fire-altered plant matter. In: Sediment Records of Biomass Burning and Global Change, J. S. Clark, H. Cachier, J. G. Goldammer, and B. Stocks, eds., pp.9-22. Berlin: Springer Velag.

Machette, M.N.

1985 Calcic soils of the southwestem United States. In: D.L. Weide (ed.) Soils and Quatemary geology of the Southwestern United States. Geological Society of America Special Paper 203, pp. 1-21. Boulder, Colorado.

Miller, W. M.

1978 Soil Survey of DeWitt County, Texas. U. S. Department of Agriculture, Soil Conservation Service, and the Texas Agricultural Experiment Station.

Nordt, L. C.

1992 Archaeological Geology of the Fort Hood Military Reservation, Fort Hood, Texas. U.S. Army Fort Hood, Archaeological Resource Management Series, Research Report No. 25.

Norwine, J.

1995 The regional climate of South Texas: Patterns and trends. In: The Changing Climate of Texas: Predictability and Implications for the Future, J. Norwine, J. R. Giardino, G. R. North, and J. B. Valdés, eds., pp. 138-154. Geobooks, Texas A\&M University, College Station.
Olson, G. W. (compiler)

1976 Criteria for Making and Interpreting a Soil Profile: A Compilation of the Official USDA Procedure and Nomenclature for Describing Soils. University of Kansas Publications, Lawrence.

Prewitt, Elton.

1981 Cultural Chronology in Central Texas. Bulletin of the Texas Archeological Society 52: $65-89$.

1985 From Circleville to Toyah: Comments on Central Texas prehistory. Bulletin of the Texas Archeological Society 54 (for 1983): 201-238.

Taylor, A. J. and C. L. Highley.

1995 Archeological Investigations at the Loma Sandia Site (41LK28). A Prehistoric Cemetery and Campsite in Live Oak County, Texas. Studies in Archeology 20, Volumes 1 and 2. Texas Archeological Research Laboratory. The University of Texas at Austin.

Tomka, S. A., T. K. Perttula, and R. J. Hard, eds.

1997 Archaeology of the Rio Grande and Central Coastal Plains, Texas: A Planning Document. Archaeological Survey Report, No. 266, The Center for Archaeological Research, The University of Texas at San Antonio.

Turner, E. S., and T. R. Hester.

1993 A Field Guide to Stone Artifacts of Texas Indians, Second Edition. Texas Monthly Field Guide Series. Gulf Publishing Co., Houston 


\section{APPEndix A Faunal Analysis of Site 41DW269}

\section{By Barbara A. Meissner \\ Center for Archaeological Research, University of Texas at San Antonio}

One hundred thirty-eight vertebrate faunal remains were recovered in this project. They were identified to the lowest taxonomic level possible using the comparative collection at the Center for Archaeological Research of The University of Texas at San Antonio. Most of this bone was highly fragmented, making identification of taxon below the class level difficult. In addition, bone from two lot numbers (Lots 17 and 36) was heavily encrusted with calcium carbonate, making identification, or even counting, difficult. The Number of Identified Specimens (NISP) of taxa identified to at least the genus level for the entire collection was 32 (23.2 percent). Table 1 lists taxa identification and counts for all bone. When bone could only be assigned to a class (mammal, bird, etc.) an estimation of the size of the animal was made if possible.

The bone which was heavily encrusted with calcium carbonate presented a problem. This bone was stuck together in clumps. Removal of the calcium carbonate without destruction of the bone was a fairly delicate operation. A five percent solution of acetic acid was tried, but did not dissolve the calcium carbonate well. The bone was then soaked in an acid bath of .25 normal hydrochloric acid over night. This still did not remove all the encrustation, but the exposed surfaces of bone were becoming very pitted, due to acid etching. It was decided that further soaking in an acid solution would damage the bone excessively. The bones were then rinsed in water and soaked for an hour in a solution of sodium bicarbonate to ensure that any remaining acid in the bone was neutralized. Identification of five bones was possible at this point, including portions of a femur, a sacrum, and a thoracic vertebra, all of the species Odocoileus virginianus, the white-tailed deer. The remaining bone was counted, however it should be noted that due to the remaining encrustation, this count may not be entirely accurate.

\begin{tabular}{|c|c|c|c|c|}
\hline Taxon & Common Name & Count & $\%$ of NISP & Notes \\
\hline Bison bison & American bison & & $15.60 \%$ & $\begin{array}{l}\text { There were bison known in the area } \\
\text { before } 1830 \text { (Weniger } 1997: 11 \text { ). }\end{array}$ \\
\hline Crotalus cf. atrox & $\begin{array}{l}\text { Western diamondback } \\
\text { rattlesnake }\end{array}$ & 1 & $3.10 \%$ & \\
\hline Didelphis virginiana & Opossum & 4 & $12.50 \%$ & \\
\hline Lepus californicus & Blacktailed lackrabbit & 2 & $6.30 \%$ & \\
\hline Odocoileus virqinianus & White-tailed deer & 19 & $59.40 \%$ & \\
\hline Sylvilagus sp. & Cottontail rabbits & 1 & $3.10 \%$ & $\begin{array}{l}\text { Ranges of } 2 \text { species (S. aquaticus, } \\
\text { and S. floridanus) overlap in the } \\
\text { area (Davis and Schmidly } 1994: 88 \text {, } \\
92 \text { ) }\end{array}$ \\
\hline & (20) & 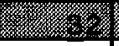 & 3.2. & \\
\hline Artiodactyl & Deer goat or sheep & 1 & & \\
\hline Bovinae & Bison or cow & 3 & & \\
\hline Mammalia & Mammal & 82 & & \\
\hline (Small) & Rabbit-sized mammal & 1 & & \\
\hline (Large) & $\begin{array}{l}\text { Deer or antelope-sized } \\
\text { mammal }\end{array}$ & 2 & & \\
\hline (Very Large) & $\begin{array}{l}\text { Bison, horse or cow-sized } \\
\text { mammal }\end{array}$ & 1 & & \\
\hline Aves (Large) & Duck-sized bird & 4 & & \\
\hline Testudinata & Turtle & 4 & & \\
\hline \multirow[t]{2}{*}{ Vertebrata } & $\begin{array}{l}\text { Vertebrate, class } \\
\text { indeterm inate }\end{array}$ & 8 & & \\
\hline & Total & 138 & & \\
\hline
\end{tabular}


The following observations were made on all bone:

Taxon. Identification was made to the lowest possible taxonomic level. Identification was conservative, i.e., bovid bones and teeth were not assumed to be Bison unless they could be positively differentiated from Bos (domestic cattle).

Count. Each bone was counted separately, even when it was possible to refit them.

Weight $(\mathrm{g})$. Bone from the two heavily encrusted lots was not weighed, as the encrustation would seriously bias this measurement.

Element. Identification of body element was made, when possible.

Portion. Identification of portion of the element (e.g., "distal 1/3," or "fragment of diaphysis").

Side. In paired elements, side was recorded when identifiable.

Pitting. Degree of chemical weathering of the bone surface was coded as follows:

$0=$ No evidence of chemical weathering;

$1=$ Small amount of pitting on portions of the bone surface;

$2=$ Entire bone surface is pitted. Bone feels rough;

$3=$ Surface of bone is eroded and pitting of

subsurface bone is continuing. Bone has "chewed" look;

$4=$ Subsurface bone is heavily pitted. Bone is friable and crumbling;

In=Degree of pitting could not be determined.

Weathering. Evidence of atmospheric weathering was coded as follows:

$0=\mathrm{N} 0$ evidence of atmospheric weathering;

$1=$ Presence of fine longitudinal cracking on long bones, and/or slight roughening of bone surface;

$2=$ Longitudinal cracks are more numerous, longer and deeper. Mosaic cracking on articular surfaces is present, and some exfoliation of surface may be present;

$3=$ Cracks may extend to marrow cavity and are splintering. Extensive exfoliation of bone surface. Bone may have "bleached" appearance;

$4=$ All surface bone has exfoliated. Bone extremely cracked, and is soft and crumbling;

In=Degree of atmospheric weathering could not be determined.

Burned. Evidence of heat alteration of bone was

coded as follows:

$0=$ No evidence of heat alteration;

$1=B$ one appears to be stained by smoke, but is not charred;

$2=$ Some portion of bone is charred black;

$3=$ Bone is charred and partially calcined;

$4=$ Bone is completely calcined and is white, brown or gray in color.

Evidence that animal was a sub-adult. Possible juvenile characteristics include unsealed epiphyseal joints and deciduous teeth.

Gnawed. Evidence that bone was gnawed by animals, including rodents and carnivores.

Modifications. Evidence of deliberate modification by humans. This includes evidence of butchering marks and evidence that bone was broken while still fresh.

Notes. Includes other observations and remarks.

A complete provenienced list of the observations listed above is included at the end of this report (Table 2).

All of the identified genera are native to the region either today or in the historic past, and are commonly found in archaeological sites in South Texas (Tomka et al. 1997; Weniger 1997). The small sample size does not allow an estimation of relative abundance. The Minimum Number of Individuals (MNI) for the entire collection is 1 for each identified species. If the heavily encrusted bone is grouped separately, the MNI for whitetailed deer (O.virginianus) becomes 2 and all others remain 1 .

Seventy-two bone (52.2 percent) exhibit heat alteration. Of these. 39 (54.2 percent) were calcined or partially calcined, indicating exposure to high heat and/ or long duration of heating (see Lyman 1994: 388-389). This may indicate deliberate disposal of bones in fires. It has been shown experimentally that natural conditions fires will regularly carbonize bone but rarely calcine them. The presence of large amounts of calcined bone can be used to infer human-controlled fires (Lyman 1994: 389).

Nineteen bones (13.8 percent) showed evidence of deliberate modification by humans, including bones broken while fresh. Sixteen bone showed butcher marks, including chop marks, thins cuts, and peck marks (see Table 2). Eleven of these bones are of particularinterest. These are fragments of the diaphysis of the left humerus of a white-tailed deer which have been incised. One set is a portion of the diaphysis near the proximal end, and is composed of six fragments which refit (Figure 1). The proximal end may have been cut-and-snapped. At least two grooves were cut in the bone, both short and somewhat diagonal to the long axis of the bone. Bone appears somewhat smoke-stained and has a light calcium carbonate deposit on it. The other set is a portion of the medial diaphysis, composed of five fragments which refit (Figure 2). It is possibly from the same element as the one in Figure 1, since in addition to the presence of incising, the size, color, and amount of calcium carbonate deposits are all similar. It has two thin, shallow grooves cut parallel to each other and to the long axis of the bone, about $1.5 \mathrm{~mm}$ apart. Two grooves were also cut at a 90 degree angle to the long axis of the bone. One is shallow and fairly short, the other is deep and measures about one $\mathrm{mm}$ wide. On each end the bone 
seems to have snapped away from grooves. The impression is that this incising was intended for practical rather than decorative purposes.

This collection contains a very small sample of bone, a common occurrence in archaeological sites in the region of the project. Poor preservation of faunal material is a perennial problem in South Texas (Tomka et al. 1997) due to a combination of factors, including both cultural and non-cultural taphonomic processes. While evidence of both chemical weathering (pitting of hone surface) and atmospheric weathering was present in this collection, none of the bone appeared to be heavily affected by either of these taphonomic processes. This suggests that few hone were deposited there in the first

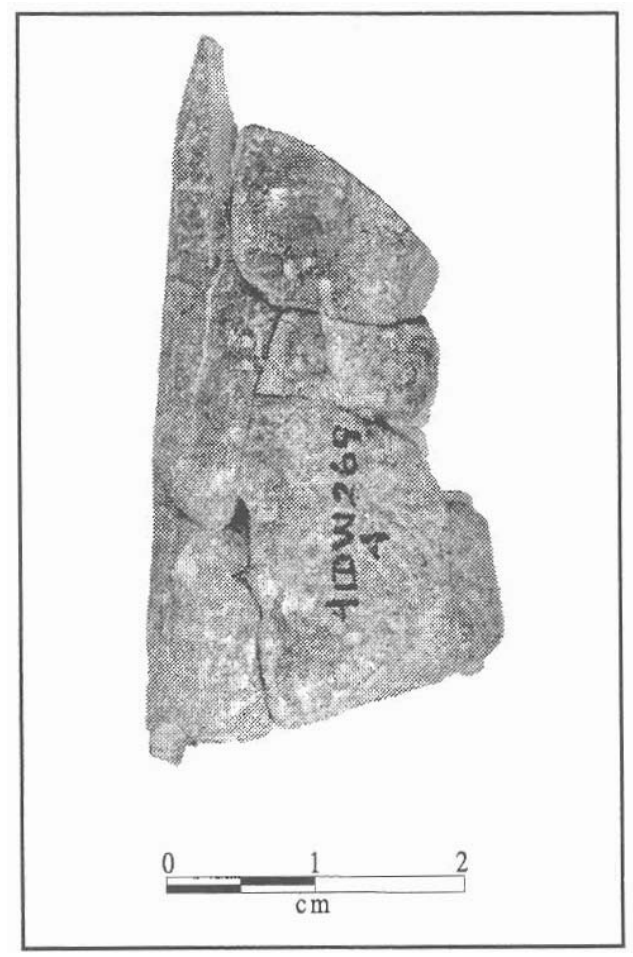

Figure A 1. Segment of deer humerus in 6 pieces with short incised marks. place. However, the study of the natural taphonomic processes which affect bone in South Texas sites remains at an early stage, and any conclusions drawn concerning effects of natural versus human-caused taphonomic factors must be considered tentative.

The large number of sites in South Texas from which few or no vertebrate remains can be recovered makes even very small collections like this one important (Tomka et al 1997: 5-34). Although individually this sample is too small to make generalizations about prehistoric diet in the region, when combined with information from other sites in the area, these data will allow a better picture of the prehistoric utilization of animals to be made.

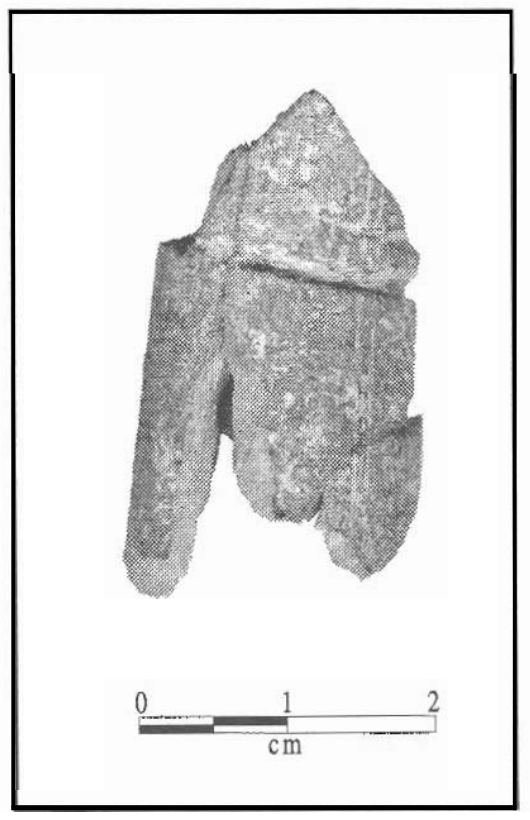

Figure A 2. Segment of deer humerus in 5 pieces, showing incised grooves. 
Table 2. Provenienced list of all bone, with coded observations.

\begin{tabular}{|c|c|c|c|c|c|c|c|c|c|c|c|c|}
\hline \multirow{2}{*}{\begin{tabular}{|c|}
\multicolumn{1}{|c|}{ Taxon } \\
Lot \#1 \\
\end{tabular}} & \multirow{2}{*}{\multicolumn{2}{|c|}{ ICt.Wpt. (p) }} & \multirow{2}{*}{ Element } & \multirow{2}{*}{ Portion } & \multicolumn{2}{|c|}{ Side Pit } & Wea & \multirow[t]{2}{*}{ Bra } & \multirow[t]{2}{*}{ Juvenile } & \multirow[t]{2}{*}{ Gnawed } & \multirow[t]{2}{*}{ Modifications } & \multirow[t]{2}{*}{ Notes } \\
\hline & & & & & & & & & & & & \\
\hline Aves (Large) & 1 & 0.53 & Long bone & Fragment & & 0 & 0 & 0 & & & & \\
\hline Bison bison & 1 & 5.58 & $\begin{array}{l}\text { Upper 1st } \\
\text { premolar }\end{array}$ & Mesial $1 / 2$ & $\mathbf{R}$ & 0 & 0 & 0 & & & & \\
\hline Bison bison & 1 & 21.58 & Cranium & Fragment & & 0 & 1 & 0 & & & & \\
\hline Mammalia & 1 & 2.87 & Long bone & Fragment & & 0 & 2 & 0 & & & & \\
\hline Mrmmalia & 1 & 0.51 & & & & 0 & 1 & 0 & & & & \\
\hline Mammalia & 1 & 0.21 & & & & In & In & 0 & & & & \\
\hline $\begin{array}{l}\text { Mammalia (Very } \\
\text { Large) }\end{array}$ & 1 & 7.21 & Cranium & Fragment & & 0 & 1 & 0 & & & & \\
\hline Lot \#2 & 7 & 3849 & & & & & & & & & & \\
\hline Bison bison & 3 & 52.41 & $\begin{array}{l}\text { Upper 3rd } \\
\text { molar }\end{array}$ & $\begin{array}{l}\text { All butlingual } \\
\text { side }\end{array}$ & $\mathrm{R}$ & 0 & 0 & 0 & & & & 3 fragments of tooth \\
\hline \begin{tabular}{|l|} 
Mammalia \\
\end{tabular} & 1 & 3.42 & & & & 0 & 0 & 0 & & & & \\
\hline Mammalia & 3 & 3.05 & Long bone & Fragment & & 0 & 2 & 0 & & & & \\
\hline
\end{tabular}

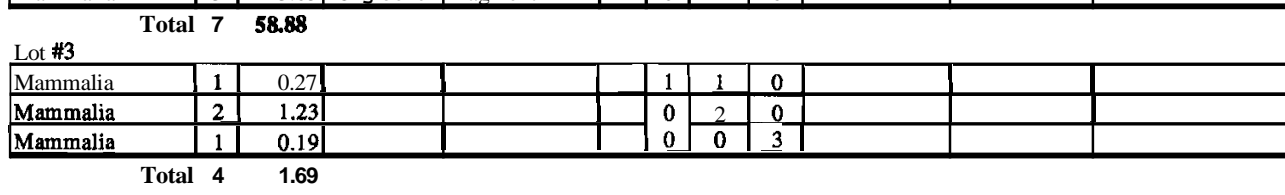

\begin{tabular}{|c|c|c|c|c|c|c|c|c|c|c|c|c|}
\hline Artiodactyl & 1 & 1.10 & $\begin{array}{l}\text { Kadial } \\
\text { carpal }\end{array}$ & Complete & $\mathrm{L}$ & 0 & 1 & 0 & & & & \\
\hline $\begin{array}{l}\text { cf. Odocoilews } \\
\text { virginianus }\end{array}$ & 6 & 5.921 & Humerus & $\begin{array}{l}\text { Fragment of the } \\
\text { diaphysis }\end{array}$ & $\mathrm{L}$ & 2 & 1 & 1 & & & see text & $\begin{array}{l}6 \text { fragments which mend. It looks like pan } \\
\text { of the diaphysis of a deer humerus (left) up } \\
\text { near the proximal end. }\end{array}$ \\
\hline $\begin{array}{l}\text { cf. Odocoileus } \\
\text { virginianus }\end{array}$ & 5 & $6.22 \mathrm{l}$ & Humerus & \begin{tabular}{|l|} 
Fragment of the \\
diaphysis
\end{tabular} & $\mathrm{L}$ & 2 & 0 & 1 & & & see text & $\begin{array}{l}5 \text { fragments which mend. It looks like the } \\
\text { medial diaphysis of a deer humerus (left), } \\
\text { possibly the same one as above. }\end{array}$ \\
\hline Crotalus cf. atrox & 1 & 0.21 & Vertebra & $\begin{array}{l}\text { All but spinous } \\
\text { process }\end{array}$ & & 0 & 0 & 0 & & & & \\
\hline Mammalia & 1 & 0.15 & & & & \begin{tabular}{|l|l}
0 \\
\end{tabular} & 0 & 0 & & & & \\
\hline Mammalia & 9 & 4.37 & & & & In & In & 4 & & & & Thin calcium carbonate crust \\
\hline Mammalia (Large) & 1 & 0.24 & & & & In & In & 1 & & & $\begin{array}{l}\text { Shallow groove on } \\
\text { surface }\end{array}$ & $\begin{array}{l}\text { appears to go with (but does not mend) the } \\
\text { next } 2 \text { bones }\end{array}$ \\
\hline Testudinata & 1 & 0,36 & Carapace & Fragment & & 0 & 0 & 0 & & & & Small \\
\hline
\end{tabular}

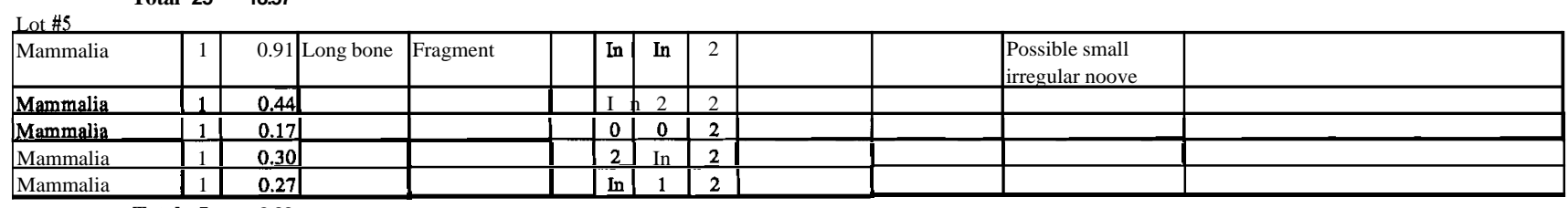

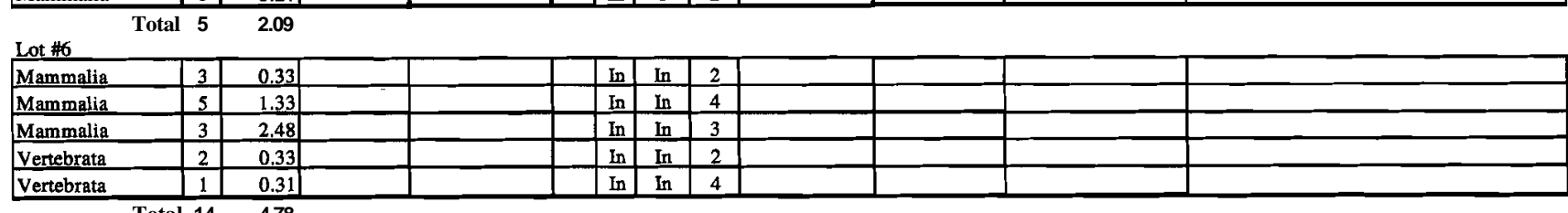

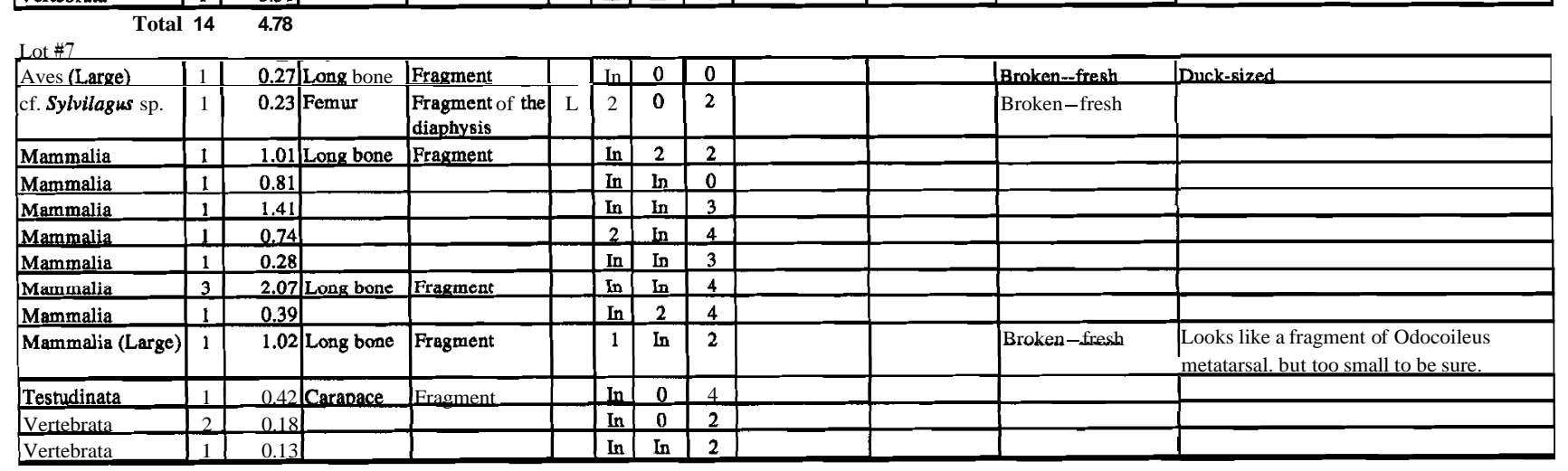

$\begin{array}{lll}\text { Total } 16 & \mathbf{8 . 9 6}\end{array}$




\section{References Cited}

Davis, W. B. and D. J. Schmidly 1994 The Mammals of Texas. Texas Parks and Wildlife, Austin.

Lyman, R. L. 1994 Vertebrate Taphonomy. Cambridge University Press, Cambridge.

Tomka, S. A., B. A. Meissner, and T. K. Perttula 1997 Hunter-Gatherer Subsistence Practices.
In Archaeology of the Rio Grande and Central Coastal Plains, Texas: A Planning Document. Volume 1. Archaeological Survey Report No. 266, Center for Archaeological Research, The University of Texas at San Antonio. Review Draft.

Weniger, D.

1997 The Explorers' Texas. Vol. 2: The Animals They Found. Eakin Press, Austin, TX. 
$38 \quad$ Significance Testing at Prehistoric Archeological Site... 


\section{Appendix B Thin-section Description of Carbonate Specimen}

\section{BY L. E. Garner \\ Bureau of Economic Geology University of TeXas at Austin}

This report describes the results of a petrographic examination of a carbonate rich mass found in the B Horizon of an alluvial soil at site 41DW269 in DeWitt County, Texas. In hand specimen the specimen is white and appears to be composed primarily of tine to very tine grained calcium carbonate. The material is soft, friable and porous.

A thin-section was prepared bv National Petrographic in Houston. The specimen was vaccum impregnated with blue epoxy and stained for calcite. The calcite shows as light brown in the accompanying photographs(Figure B1 and B2). Quartz grains and rock fragmentsare light gray to white in the photographs. Pore space is filled with the blue epoxy.

Porosity: Pore space in the specimen ranges from about $20 \%$ to $\mathbf{4 0} \%$ depending on the location within the sample.

Composition: About $75 \%$ to $80 \%$ of the mineral

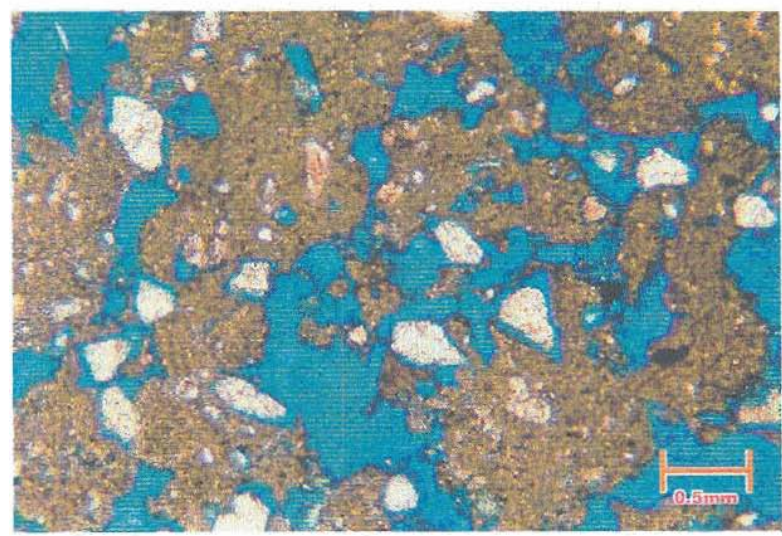

FigureB1. Thin section of carbonate mass. material in the specimen is cryptocrystallinecalcite. Angular quartz grains account for about $\mathbf{2 0 \%}$ to $25 \%$ of the total mineral material. Angular rock fragments comprise about $1 \%$ of the specimen.

Several dark brown particles (less than 1\%) are also present in the specimen (see photographs). These particles are opaque and show as dark brown spots in reflected light. The particles occur in a random fashion and are probably organic material.

Grain-size: The angular grains in the calcite matrix range from a maximum size of about $0.5 \mathrm{~mm}$ to less than $0.01 \mathrm{~mm}$

Unusual aspects of the specimen include the occurrence of the "organic particles" mixed in the specimen and the w mbiii on of tine grained calcium carbonate and angular quartz grains. Both of these conditions seem to indicate that the specimen was manmade.

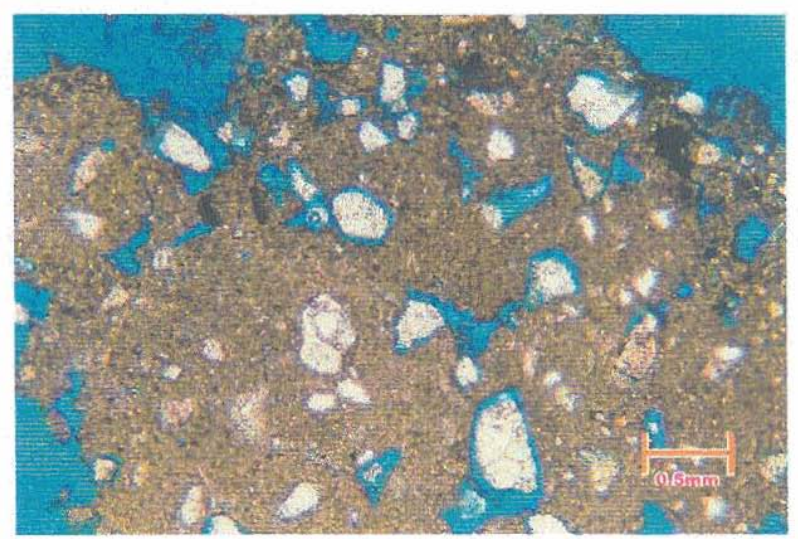

Figure BQ. Thin section of carbonate mass. 